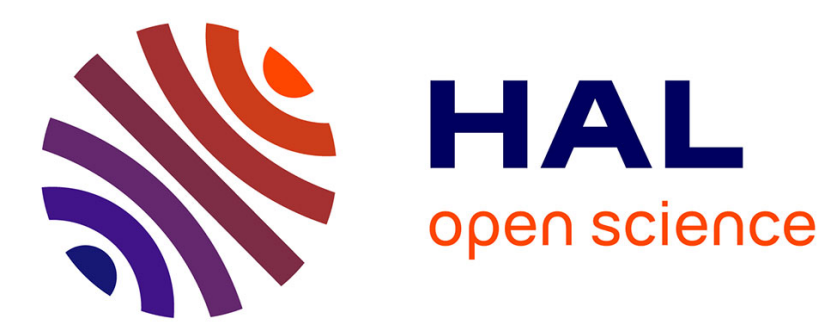

\title{
Bagan murals and the Sino-Tibetan world
}

Claudine Bautze-Picron

\section{- To cite this version:}

Claudine Bautze-Picron. Bagan murals and the Sino-Tibetan world. 2014. hal-01099967

\section{HAL Id: hal-01099967 https://hal.science/hal-01099967}

Preprint submitted on 5 Jan 2015

HAL is a multi-disciplinary open access archive for the deposit and dissemination of scientific research documents, whether they are published or not. The documents may come from teaching and research institutions in France or abroad, or from public or private research centers.
L'archive ouverte pluridisciplinaire HAL, est destinée au dépôt et à la diffusion de documents scientifiques de niveau recherche, publiés ou non, émanant des établissements d'enseignement et de recherche français ou étrangers, des laboratoires publics ou privés. 


\title{
Bagan murals and the Sino-Tibetan world
}

\author{
Claudine Bautze-Picron \\ CNRS, UMR 7528 'Mondes Iranien et Indien'
}

\section{Introduction}

Located in the central plain of Burma on the left bank of the Irrawady, the old city of Bagan was at the centre of an intensive commercial network with roads following the river from north to south, others crossing the hills on the western bank of the river, reaching Arakan and beyond the Indian subcontinent, or going toward Yunnan, China, Tibet and Central Asia in the east and the north. These commercial contacts were backed by political and diplomatic relations, which also linked the kingdom of Bagan to those of Sri Lanka and Angkor.

Being thus at a centre of this intricate network had profound repercussions on the art of the site, a phenomenon which has been only too rarely noted, let alone studied in detail. Most authors considered the Indian, and more in particular Bengalese, impact on the architecture of the site, or introduced remarks about the similarities between specific images from Bagan and Eastern India. Systematic study of these similarities, as indeed of those noted between the art of Bagan and China, is however still wanting. Study of the wall paintings from this standpoint is in fact richly rewarding: unlike the stone and cast images found at Bagan, which show such strong similarities with the art of Eastern India that one can at times surmise them to have been imported from this region and not produced locally, murals are immovable and were produced where they are still seen today. They thus reflect a local reality even if penetrated by elements whose origin can be traced back to India or China.

As a matter of fact, the wall paintings which can be dated from the end of the eleventh up to the early fourteenth century share features of various types with the artistic productions of China and Eastern India. They offer a varied range of information which have already drawn our attention in recent years: those of the late eleventh and early twelfth centuries illustrate characters wearing garments adorned with motifs encountered in Buddhist illuminated manuscripts from around 1100 A.D. produced in the region of Comilla in Bangladesh; ${ }^{1}$ the style and the iconography of the paintings in a temple like the Loka-hteik-pan (beginning of twelfth century) go back to the art of Bihar; ${ }^{2}$ and even if their iconography appears to relate to literary sources traditionally considered to belong to Theravāda, the murals in temples like Patho-hta-mya and Mye-bon-tha-hpaya share their style with eleventh-twelfth-centuries illuminated manuscripts from Eastern India. ${ }^{3}$

The iconography and style imported from Eastern India in the eleventh century - most probably because painters of Indian origin had then been invited to work and found ateliers in Bagan - rapidly underwent fundamental transformations when local painters succeeded their Indian masters. The pictorial development of the twelfth century led to

\footnotetext{
${ }^{1}$ Bautze-Picron 2014.

${ }^{2}$ Bautze-Picron 2003: 8-9 and passim.

${ }^{3}$ Bautze-Picron in press.
} 
the emergence of a genuine Burmese style which also radically modified iconographic topics inherited from Eastern India, such as Bodhisattva as door protectors; this movement persisted up to the early fourteenth century with the basic modification of letting the iconography become subsidiary to decorative paintings. With the Indian impact waning in the course of the twelfth century, new inspirations were embraced by the painters, to be seen in the ornamentation of Chinese garments and ceramics from the Song and Yuan periods. ${ }^{4}$

Paintings were made not by monks but by trained craftsmen. And although they were told what to represent by monks or donors, the source of inspiration for the formulation which they gave to this iconography lay in their physical environment. Thus even if the iconography of the murals refer to texts known in Sri Lanka and iconographic models could also be imported from Eastern India in the eleventh and early twelfth centuries artists were open to foreign aesthetics made accessible through the import of Indian cottons and Chinese silk and ceramics. We recently had the opportunity to study some of these aspects of the murals in various papers ${ }^{5}$ but many more questions and unknowns remain; here we will dwell on two of them in particular. As mentioned above, the painters were acquainted with various decorative motifs through Chinese garments and ceramics ${ }^{6}$ but certain aspects of the iconography constitute evidence of the local presence of Chinese or Mongols in the thirteenth or early fourteenth centuries.

Not only did the Bagan artists integrate in their production stylistic, iconographic and ornamental features from the countries adjacent to Burma, but their works were also able, albeit to a limited extent, to inspire their colleagues from abroad. The Burmese impact, most probably originating from Bagan, is in fact perceptible in various regions: around Bodhgaya in Bihar, in Bengal, at Khara Khoto in Central Asia, or even in the treasure of the Three Pagodas of the Chongsheng Temple in the Dali kingdom (937-1253). Although these examples remain isolated and never deeply anchored in the local artistic production, they prove the existence of contacts between these various regions and sites and Bagan. ${ }^{7}$

The reader will find below a list of various types of motifs seen in Bagan and also noted in different sites of the Sino-Tibetan world. These similarities are epiphenomena and generally isolated: an image at Bagan can relate to several examples noted outside the site, or a picture seen abroad is correlated with different examples observed at Bagan. Moreover, some particular iconographic aspects of the murals do not enter into this category of 'similarities' but reflect the presence of Chinese or Mongols in Bagan.

\footnotetext{
${ }^{4}$ Bautze-Picron in press.

${ }^{5}$ Bautze-Picron 2014 and in press.

${ }^{6}$ Bautze-Picron in press.

${ }^{7}$ Reference here is to a unique small crystal rock carving of the Buddha found in the treasure of the Three Pagodas and approximately dated in the $12^{\text {th }}$ c., see Lutz (ed.) 1991: 173-4, Kat. 47; Lutz 1991: 107 \& 110 , Abb. 91. See also Leoshko 1990 for an introduction on the Burmese impact in Bengal.
} 


\section{The 'short-necked' Buddha}

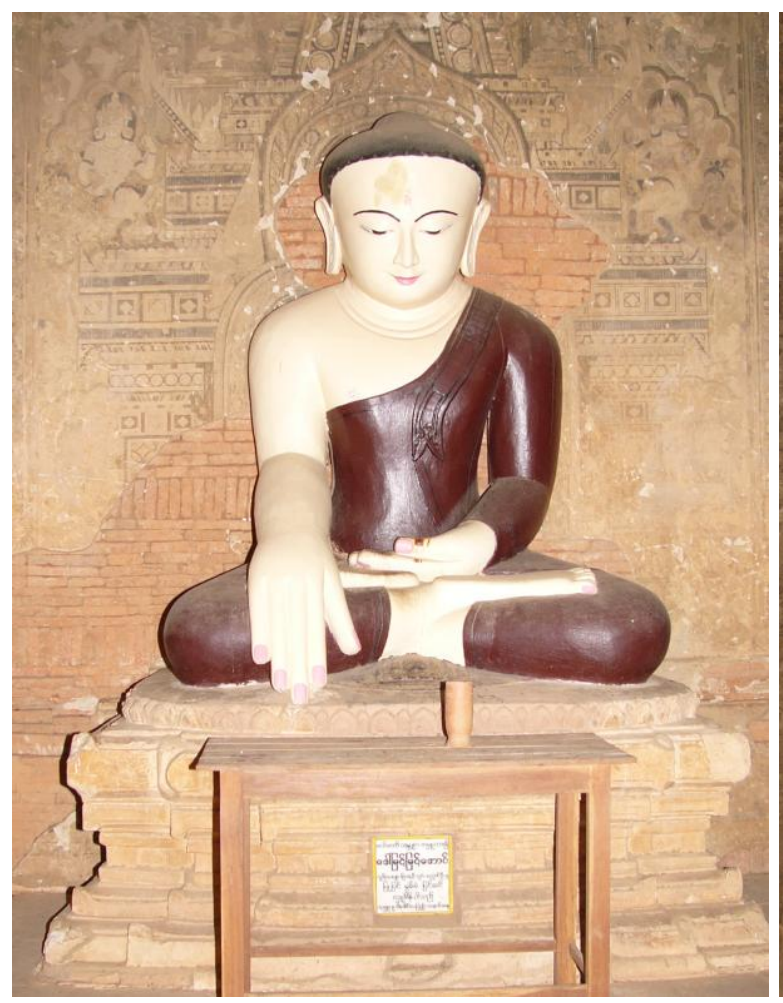

Fig. 1

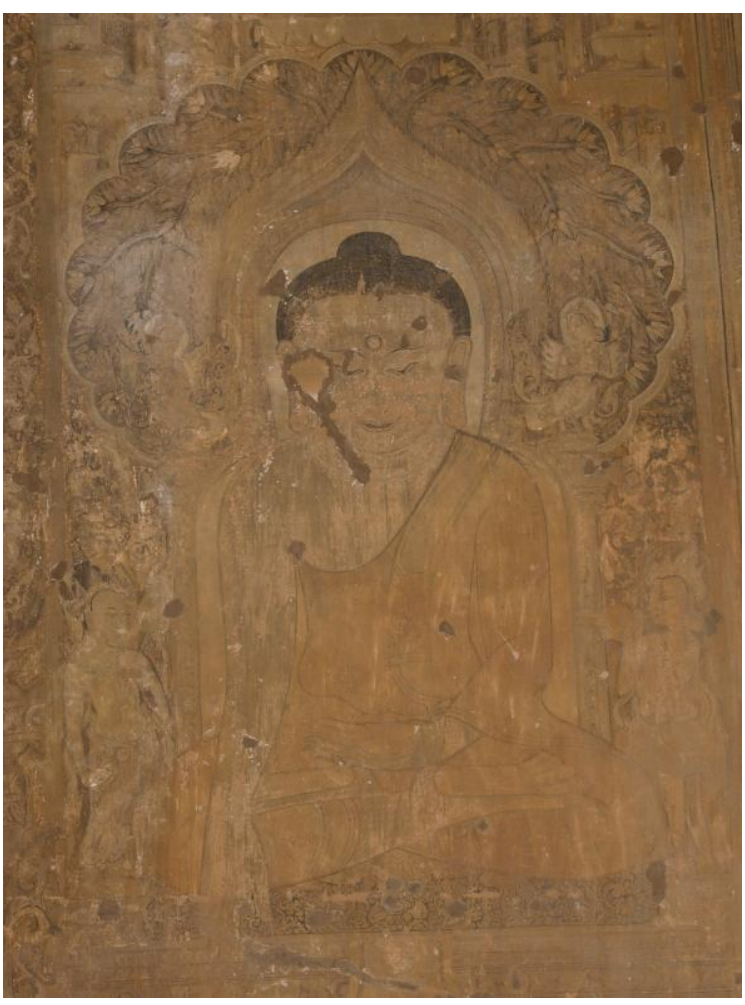

Fig. 2

The cult images of the Bagan temples present a very particular depiction of the Buddha image with round shoulders and deep-sunken head hiding the (short) neck, which is also introduced in the wall-paintings in the course of the $12^{\text {th }}$ century (Fig. 1). Outside Bagan, where it is practically generalized, this type is occasionally observed among the clothpaintings of the Tangut period collected at Khara-Khoto, where different foreign styles Nepalese, Chinese, and Tibetan - are noted, reflecting the international culture of the Buddhist community.

This type, variously labelled robust or short-necked, ${ }^{8}$ might not have been originally created by the artists of Bagan, although it is encountered there in practically all the monuments. The very technique with which the cult image was produced accounts for this 'robust' body built of bricks and stuccoed before being painted. It is highly likely that the central image of the Bodhgaya temple was made this way ${ }^{9}$ - and I would go as far as suggesting that the wall behind the image there was painted with the program of

\footnotetext{
${ }^{8}$ Terms coined by by Hiram Woodward Jr and Ulrich von Schroeder (see Bautze-Picron 2010: 72, note 11).

${ }^{9}$ The Bodhgaya image located at the centre of the Buddhist world, where Śākyamuni became buddha, was and still is the model for any further image; we should not forget that the Burmese kings were closely involved in the restoration and upkeep of the temple from the end of the $11^{\text {th }}$ century onwards. This type of production of images in brick, stuccoed and painted, spread throughout the Ganga valley as far as Bengal and Bagan and was definitely used when the cult image was of large dimensions. See Bautze-Picron 2010: 71, note 2; this is also suggested by Frederick M. Asher (2008: 29). Two clay hair scrolls discovered by Alexander Cunningham in Bodhgaya and today preserved in the British Museum (inv. 1887.0817.144 \& 145) support this hypothesis (my thanks go to Michael Willis for drawing my attention to these two objects).
} 
the Life of Śākyamuni, as found in the Loka-hteik-pan. ${ }^{10}$ Cast and carved Indian images of the Buddha from the eighth up to the late twelfth century do not however show this thickset appearance, and it is probably to be understood as reproducing the cult image of the Bodhgaya temple in the few cases in which it is to be seen. ${ }^{11}$

In the late eleventh and twelfth centuries the sculptors and bronze-makers of Bagan reproduced the main stylistic trend noted in Bihar and Bengal; only towards the end of the twelfth century do we encounter carved images of the Buddha with large head hiding his neck in the Kubyauk-nge (A.D. 1198). ${ }^{12}$ However, the cult image of the Bagan temples has always reflected a very different perception of the body of the Buddha, which is similar to the rare Indian examples mentioned above. As said above, this image is built in brick, stuccoed and painted, and owes its very characteristic form to this technique of production: the face is large and sunken, hiding the neck whereas the body is heavy, rather round, the shoulders rounded. The head does not rise free above the body but is squeezed between the shoulders on a short neck, probably to reduce its weight. The hairline generally follows evenly curved line without the wave or the peak marking the middle of the line; the uṣnis probably meant to contain a (semi-)precious stone; the forehead may be very broad. This physical appearance of the Buddha is also encountered in the thirteenth-century murals of the site and in small carved images carved in Bihar and Burma before being transmitted all over the Buddhist world, many being found in Tibetan monasteries, others in Sri Lanka or Arakan, for instance. ${ }^{13}$

One cloth-painting from Khara Khoto holds our attention here more particularly (Fig. $4),{ }^{14}$ being stylistically closely related to thirteenth-century murals of Bagan, and in

\footnotetext{
${ }^{10}$ Which would also account for this iconography of the Eight Events in numerous cloth-paintings from the Himalaya. In India, too, this iconographic model was considered to be fundamental, judging from the numerous carved depictions, in some cases of very large dimensions, such as the Jagdishpur image located near Nalanda or the remains from a similar stele discovered around Lakhi Sarai (Bautze-Picron 1995/96: 363-9).

${ }^{11}$ Also the opinion of Jinah Kim 2013: 66-70. See ibidem: figs 2-7 \& 2-8, for two painted depictions of this type. See also Bautze-Picron 2010: 71, note 2 for a further cast example found in the region of Bodh Gaya. It is highly likely that the lotus mandala preserved in the British Museum (Zwalf 1985: 115, cat. 153) also originates from the region (as also suggested by Wladimir Zwalf): the group of the Aștamahābodhisattvas surrounding the Buddha is a well-know iconography in the region (Bautze-Picron 1997).

${ }^{12}$ Reference in Bautze-Picron 2013: 71 note 10.

${ }^{13}$ Bautze-Picron 1999: figs. 1, 6, 9-10, 12-13.

${ }^{14}$ Piotrovsky 1993: 118-9, cat. 6. Two further paintings from Khara Khoto can be placed in relation to the murals of Bagan as far as the depiction of the Buddha is concerned; they show the face painted on the frame of an isosceles triangle, the base of which coincides with the hairline, and have a broad and flat uṣnissa (Piotrovsky 1993: 106-9, cat. 2; Rhie \& Thurman 1991: 341-2, cat. 135 or Menzies 2001: 88, cat. 59). All three paintings show the Buddha of the Vajrāsana, either flanked by the two Bodhisattvas Maitreya and Avalokiteśvara whose images used to stand at Bodhgaya on either side of the outer gate to the main temple (Bautze-Picron 2010: 77; but with regard to the Bodhisattvas seen on the Khara Khoto paintings, see the remark made by Rhie \& Thurman 1991: 341). The iconography within which this image is set does not, however, show any relationship to the visual language of Bagan; the tangka to which we refer more particularly shows the event of the Bodhi surrounded by a series of caityas which are symbolic of seven other sites related to the Buddha biography; this programme does not, nonetheless, reproduce the one generalized in India and Burma since the two events involving the monkey and the elephant are replaced by the evocation of the Vulture peak and the house of Vimalakirti (Piotrovsky 1993: 118). Similar observations could be made with regard to the other two cloth-paintings mentioned in this note (including, for instance, the depiction of the five Tathāgatas, the Aștamahābodhisattvas, various deities and Krodhas belonging to Esoteric Buddhism, and of Tibetan monks).
} 
particular those in the Thamuti-hpaya (monument 844, dated AD 1260) (Fig. 3), the Thambula (monument 482, dated AD 1255)(Fig. 2), the Ajja-gona-hpaya (monument 588, dated $\mathrm{AD} 1237$ ) and the Tayok-pyi-hpaya-gyi (monument 539, dated before AD $1248) .^{15}$

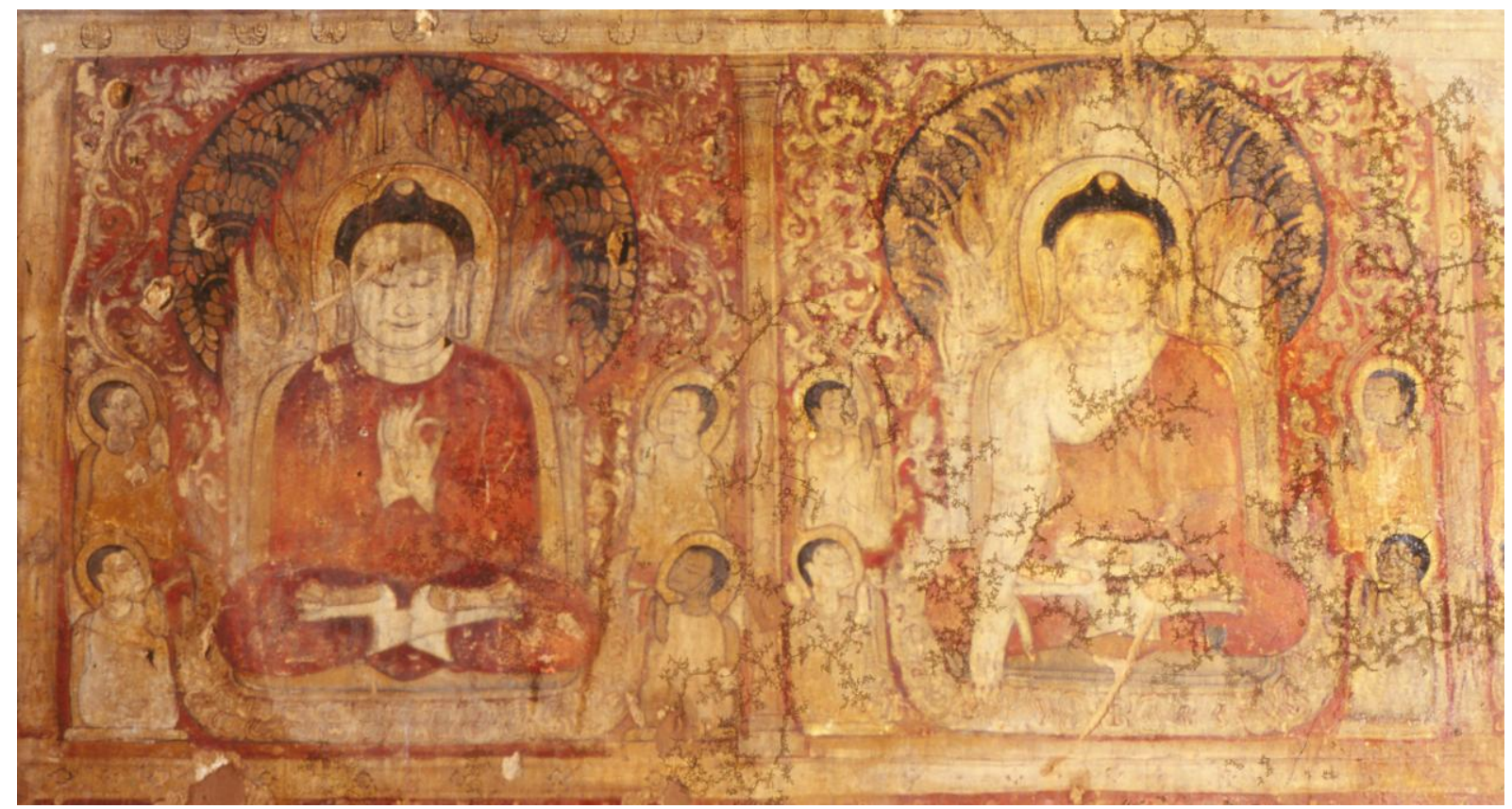

Fig. 3

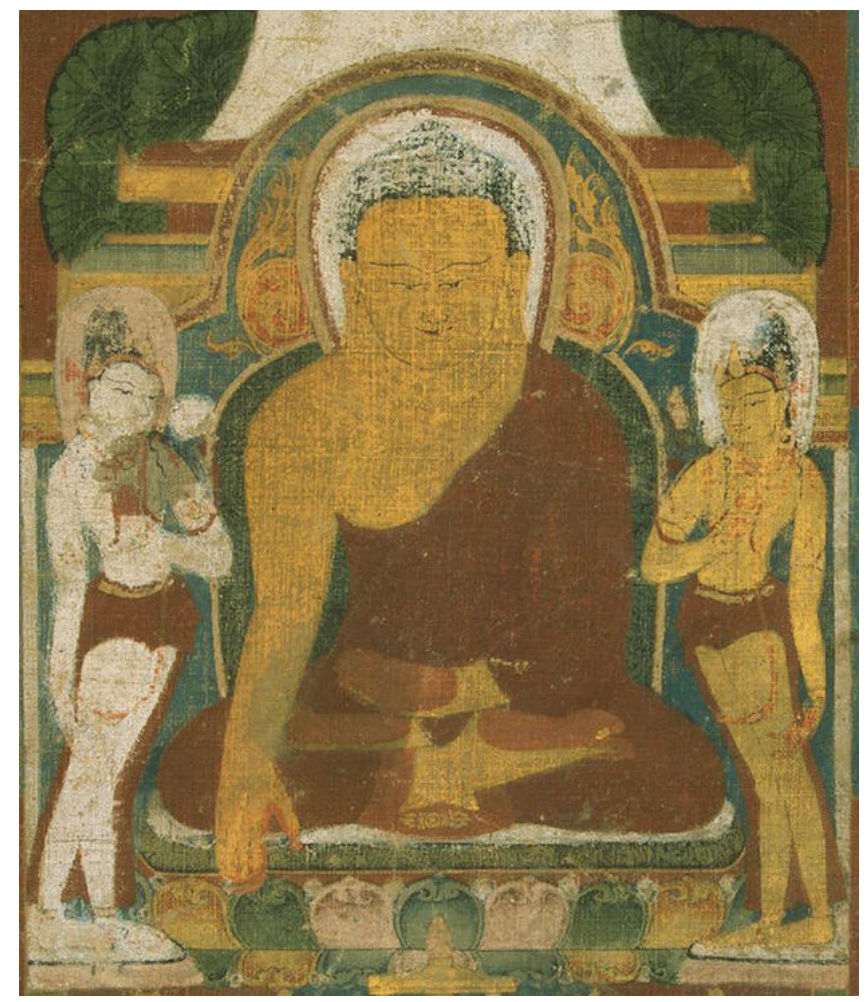

Fig. 4

\footnotetext{
15 Bautze-Picron 2003: 194-5, 198-9, 206, and plates 90. See also Pichard 1993: 300-303 (Thambula) \& 376-83 (Tayok-pyi-hpaya-gyi); 1994a: 55-59 (Ajja-gona-hpaya); 1994b: 32-35 (Thamuti-hpaya). Concerning the dating (up to the early $14^{\text {th }}$ c.) ascribed to the material found at Khara Khoto, see Stoddard 2008: 16.
} 


\section{The Buddha on the cushion}

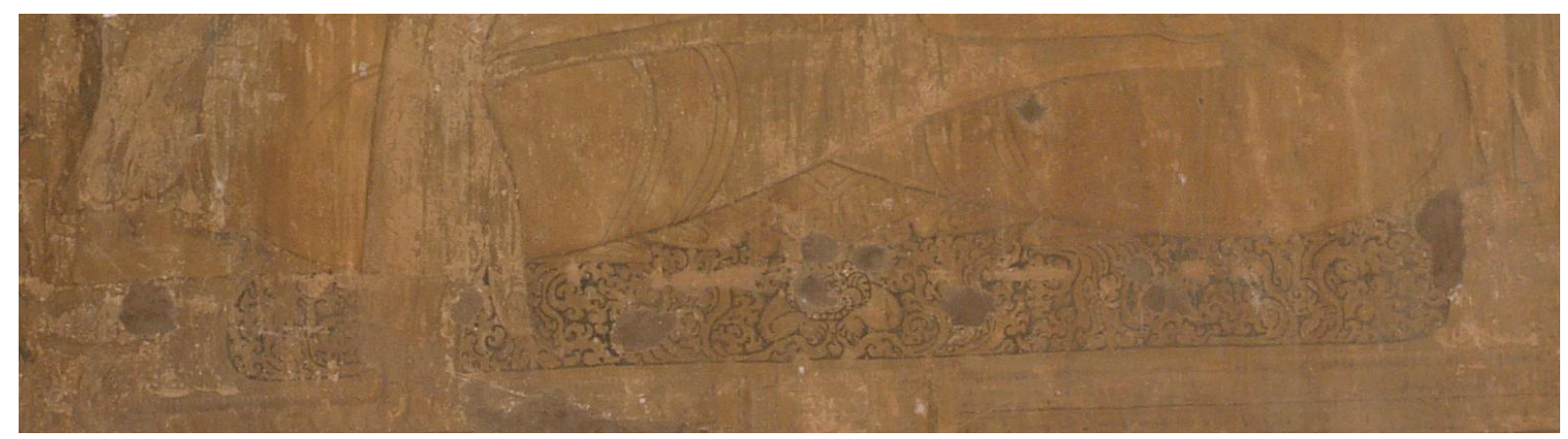

Fig. 5

Among the paintings of the Thambula mentioned above, one located in the eastern entrance hall (Fig. 5) includes a very particular element not seen in other monuments but well-known through various examples in the Indo-Tibetan world. As a matter of fact, the Buddha displaying the bhümisparśamudrā sits on a cushion adorned with intricate scrolls which spread out of the mouth of a lion face depicted at the centre of the composition. This treatment of the cushion is encountered in a number of images cast between the eleventh and thirteenth century in Eastern India and the Himalaya, showing Sākyamuni seated on a cushion adorned with a lion face in a central position; this probably alludes to the simhāsana of Bodhgaya (Fig. 6), ${ }^{16}$ a conjecture which seems to find confirmation in the fact that the motif is found beneath this Buddha only in the Thambula. All the other images in the temple depict later episodes of the Buddha's life, none in fact showing this very peculiar cushion. ${ }^{17}$ The position of the monstrous face, under the Buddha and not at the top of the image, departs totally from the traditional composition of the image in India, hence I suppose that what is initially depicted is a precious piece of cloth, perhaps a Tibetan or Chinese silk brocade, offered to a Buddha image and laid before it. ${ }^{18}$

\footnotetext{
${ }^{16}$ The Amitāyus illustrated by Pal 1972: fig. 7, being an exception. For this iconographic motif, see Pal 1972 and Weldon/Casey Singer 1999: 61-66. To the images published by these authors are to be added: von Schroeder 2001, I: pl. 85E-F (also reproduced in von Schroeder 2008: pl. 18A); and Sotheby's New York 1999: cat. 60. Of all the known examples, only one cast image was actually discovered in Bihar, and more precisely at Jaipurgarh near Fatehpur (Weldon/Casey Singer 1999: figs 31-32; on this Buddha image and the other images recovered at Jaipurgarh, see Huntington 1979, Mitra 1987, Sahai 1977, Sharma 1979).

${ }^{17}$ To this observation, we should add the presence of the two gods Indra/Sakka and Brahmā flanking the Buddha and replacing the two traditional Bodhisattvas Maitreya and Avalokiteśvara whose images used to stand in front of the Bodhi Mandir (above note 14).

${ }^{18}$ It is also possible, as suggested by D. Weldon and J. Casey, that these images refer to a very specific important image worshipped in Bihar (p. 65).
} 


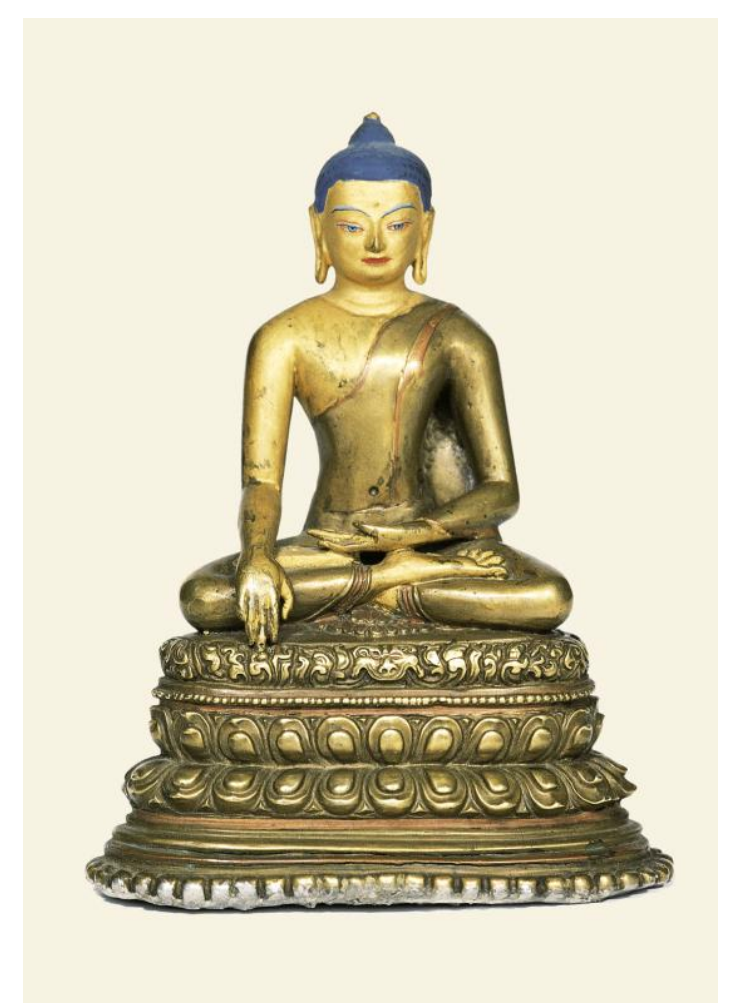

Fig. 6

\section{Foreigners in the murals}

Devotees constitute a feature included in all the murals of the site. They can be considered to be contemporary to the Buddha when observed in scenes from the Buddha's life, but they can also be the donors to the monument. Their identity remains ambivalent, however: for instance, those depicted in large groups in the Kubyauk-gyi (Myinkaba), dated $1113 \mathrm{AD}$, can be simultaneously perceived as direct disciples of the Buddha and as devotees of the twelfth century. Such large groups of lay-people are no longer present in the later murals of the site, and their original position, underneath the panel, is occupied by assemblies of monks, profiled standing or kneeling.

Because they are of human nature, the lay-people wear real garments whereas gods and goddesses or characters belonging to the Buddha's biography, such as his mother, are dressed and bejewelled in very specific ways which contribute to define an iconography inherited from north Indian models. This is observed throughout the Bagan temples, and thus the depiction of male characters wearing neither Indian nor Burmese dress might prove surprising.

As Donors in the Thambula (monument 482) ${ }^{19}$ - Within this general context the presence of an important group of foreigners whom I would tentatively identify as Mongols painted in the frame of the northern entrance to the Thambula in Minnanthu appears unusual for two reasons: on account of the appearance of these devotees, and their position within the monument (Figs 7-9). As a matter of fact, in the thirteenth century the

\footnotetext{
${ }^{19}$ Pichard 1993: 300-303.
} 
door frame was usually adorned with a covering pattern of scrolls over which flying divine figures hover. ${ }^{20}$

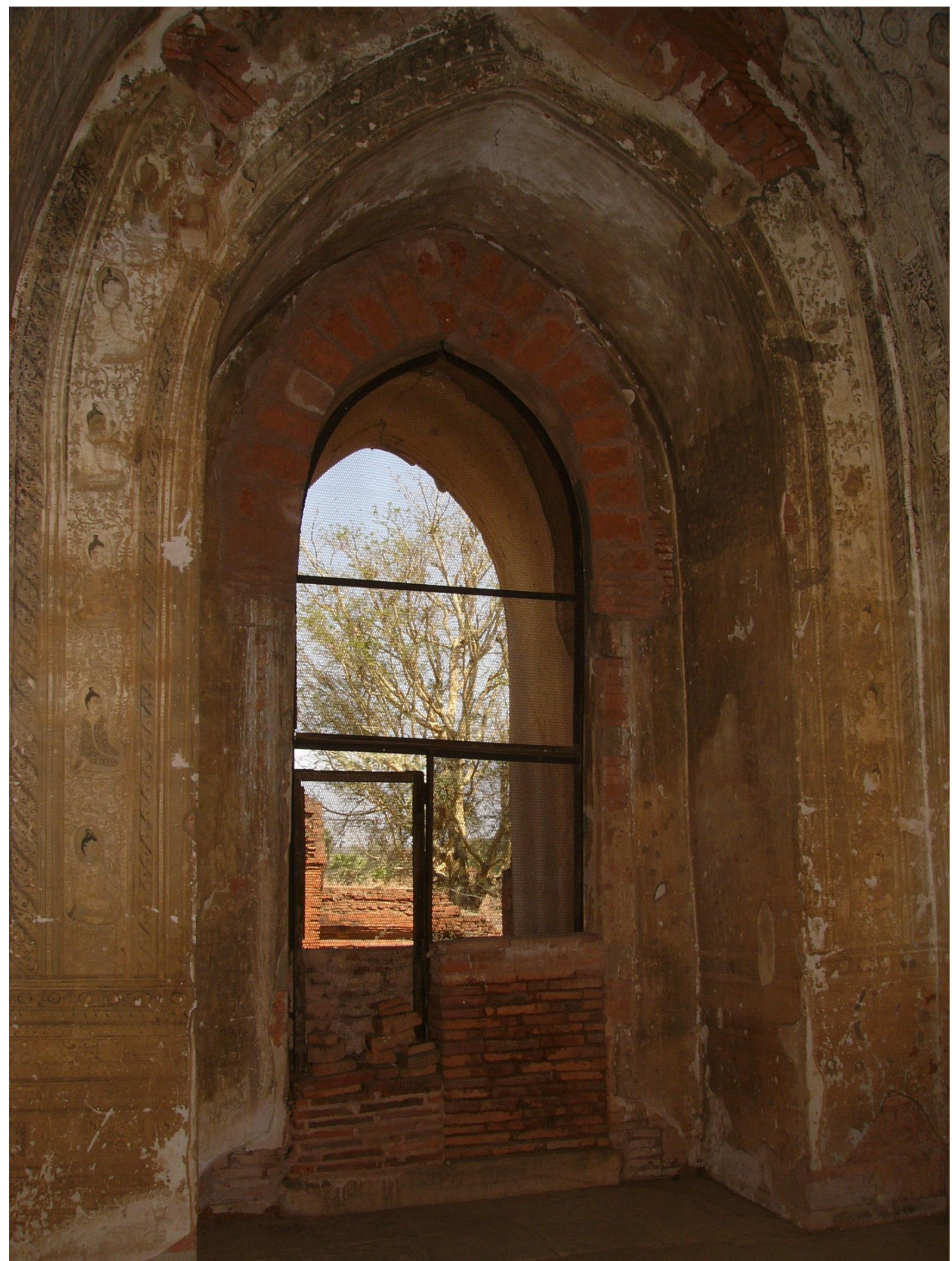

Fig. 7

${ }^{20}$ Bautze-Picron 2003: fig. 93. 
However, the northern entrance is here framed by a series of human male devotees, all kneeling with hands folded before the breast; six characters to our left and nine to our right are still preserved, the upper part of the murals having disappeared. The construction of the Thambula-hpaya was completed in 1255 A.D., having been financed by Thambula, wife to the ruler Sithu III (Uccana) (r. 1251-1256), ${ }^{21}$ but one may surmise that this group of men might also have participated in the work on the painted ornamentation of the monument and were rewarded by being portrayed at the northern entrance - perhaps because they had come from the North. The presence of the nimbus behind their heads attests yet further to their importance. ${ }^{22}$

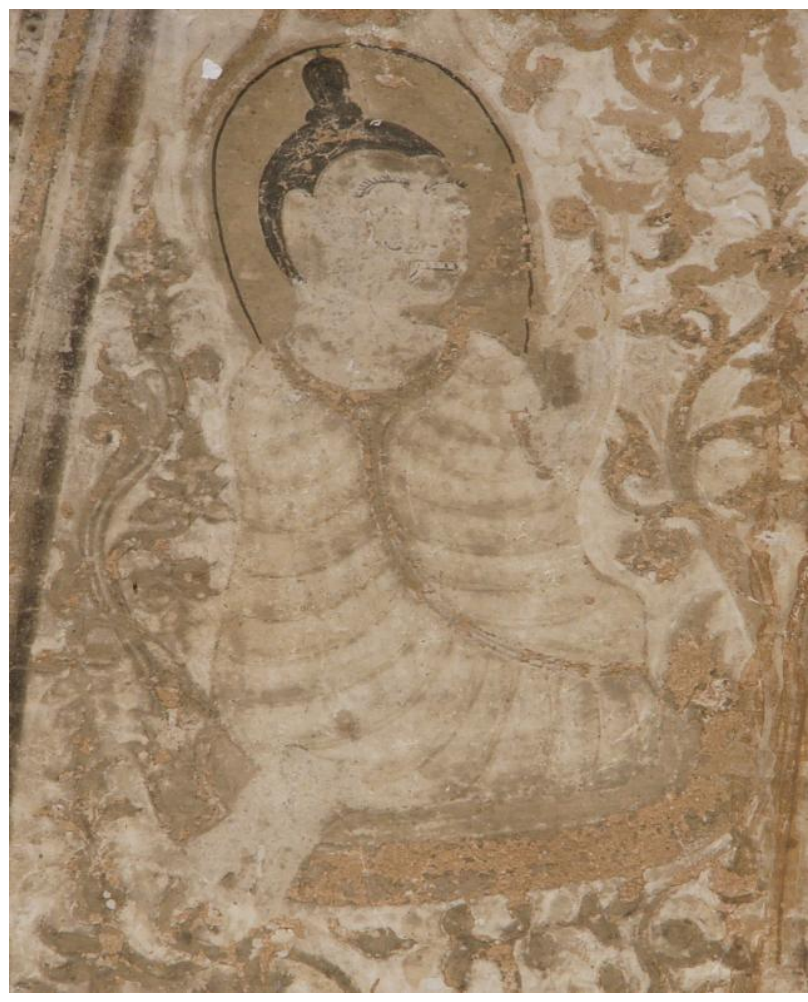

Fig. 8

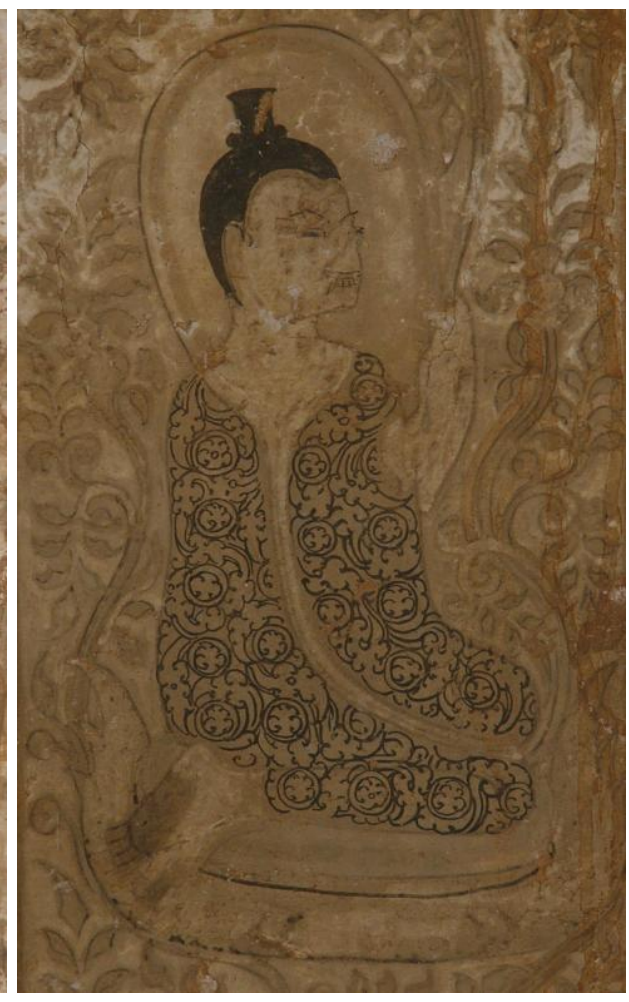

Fig. 9

Their physiognomy and dress depart from what we generally see in the site murals, obviously indicating their foreign origin. ${ }^{23}$ They display bushy moustaches hiding their mouths and falling at either end; as depicted here, this style of moustache illustrates a fashion unknown locally but noted in examples of Chinese paintings. ${ }^{24}$ Their hair is knotted at the crown of the head, also recalling a Chinese or Yuan fashion, ${ }^{25}$ while the eyebrows are not depicted with a continuous horizontal line but with tiny parallel strokes painted vertically. All are heavily clad with garments in silk brocade adorned with

\footnotetext{
${ }^{21}$ Frasch 1994: 138.

${ }^{22}$ One could also speculate that they were part of the group which accompanied the monk Disāprāmuk back from his diplomatic mission in Ta-tu (Beijing) in 1285, see below note 34 .

${ }^{23}$ Moustache and beard were not unknown at Bagan since all the male lay characters, monks excluded, wore them, but they show specific cuts: the moustache is shaped as a thin horizontal line ('à la Salvador Dali') and the beard can be full, clipped, or shaped as a long goatee. As to the long hair, it usually forms a thick bun on the nape, see Bautze-Picron 2003: figs 21-27, 48, 73, 78 for instance.

${ }^{24}$ For comparison, see: Watt 2010: 193, figs 211-212 (two inks on paper respectively dated 1296 and ca. 1041-1106); Hearn \& Smith 1996: 291, fig. 14.9.

${ }^{25}$ Ibidem; Godley 1994: 55.
} 
various motifs such as scrolls or medallions, ${ }^{26}$ but also with parallel concentric lines probably representing thick folds.

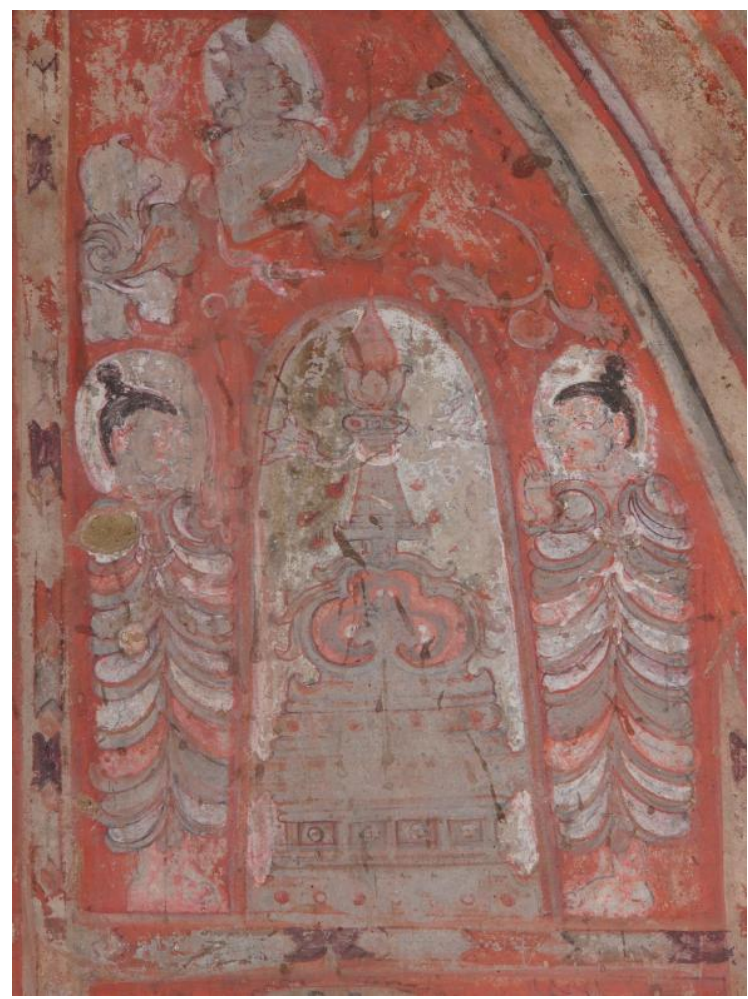

Fig. 10

As part of the iconographic programme in three monuments - Similar male figures appear in three other temples, e.g. in the Nandamanya and the Kathapa east (monuments 577 \& 505), two temples situated near the Thambula, and in monument 1077, located further West near the river. ${ }^{27}$ Whereas the murals in the Nandamanya and monument 1077 are fairly well preserved, the large panel of monument 505 which we dwell on here is unfortunately much faded and disfigured with graffiti. In all three cases, the characters are included in iconographic panels: in the Kathapa east and in monument 1077, two heavily clad characters worship a stūpa belonging to a sequence of four monuments, all depicted in the upper part of the panel (Fig. 10). In both examples, they are paired with depiction of the caitya worshipped by Nāgas at Rāmagrāma, both panels being positioned at the same height, and thus the divine level, on the wall as the Dussa-thuppa and the Cūlāmani which are respectively worshipped by the Brahmās and the Devas. ${ }^{28}$ While studying the painted programme of monument 1077, I suggested identifying this caitya as the secret underground caitya raised by Mahākāśyapa and King Ajātaśatru: this caitya contained ashes collected by Mahākāśyapa from seven of the eight original stūpas, the only one which remained intact being the one standing at Rāmagrāma. ${ }^{29}$

\footnotetext{
${ }^{26}$ For a study of volutes and scrolls as seen here and their most probable Chinese origin, see Bautze-Picron (in press).

${ }^{27}$ Pichard 1993: 331-33 (Monument 505); 1994a: 35-39 (monument 577) and 1994b: 319-21.(monument 1077).

${ }^{28}$ Bautze-Picron 2011:11-12 \& figs 15-18.

${ }^{29}$ Bautze-Picron 2011: 12 \& notes 16-17.
} 


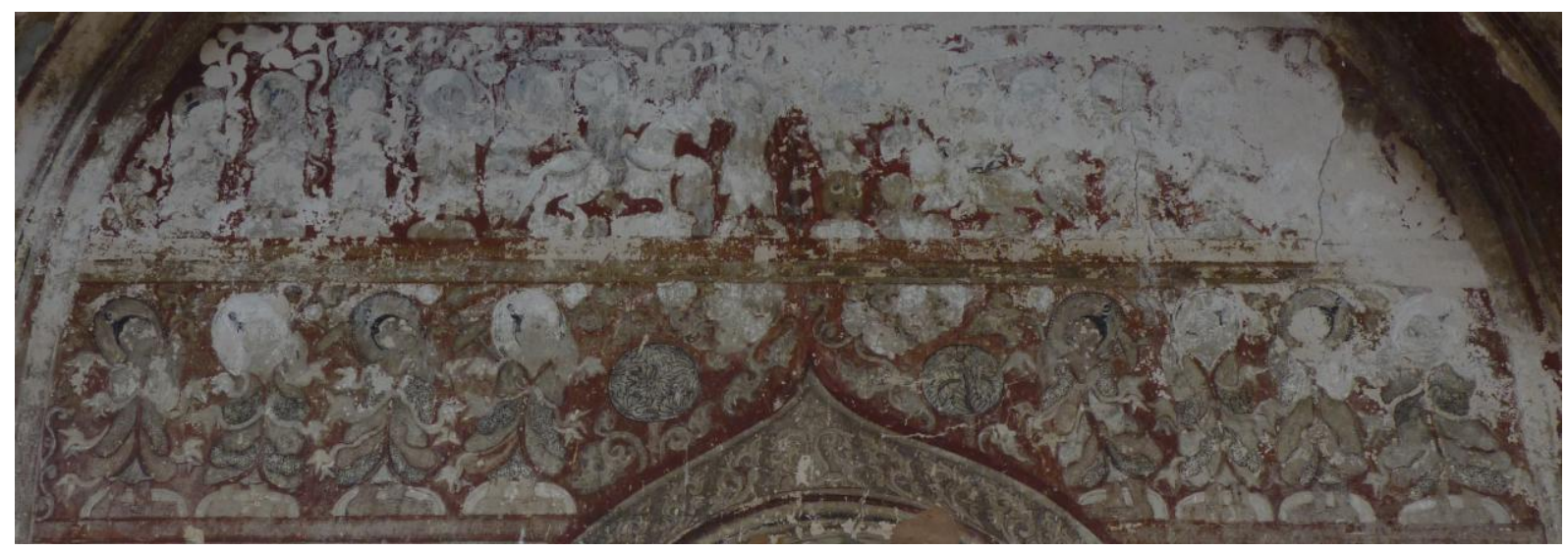

Fig. 11

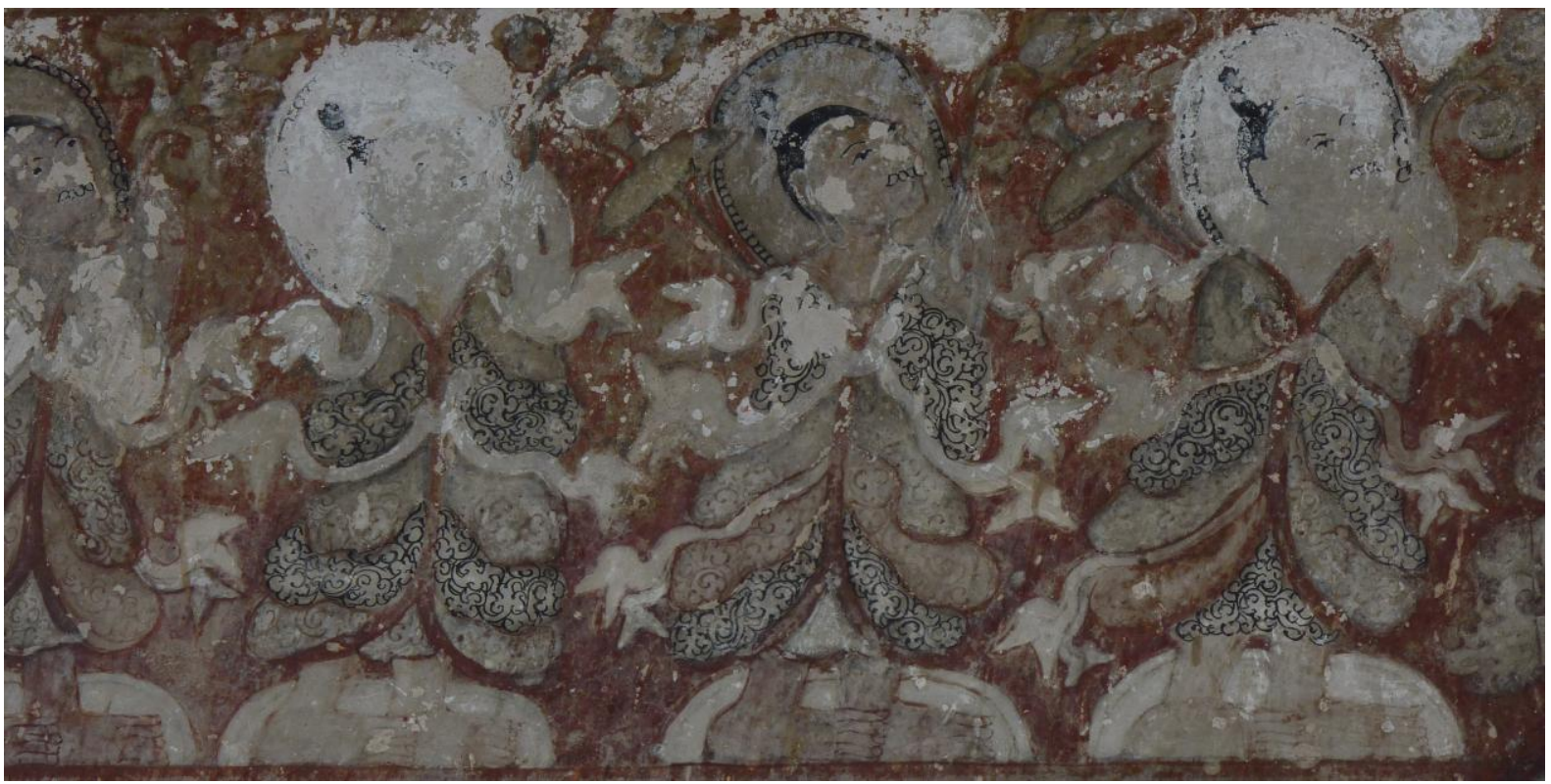

Fig. 12

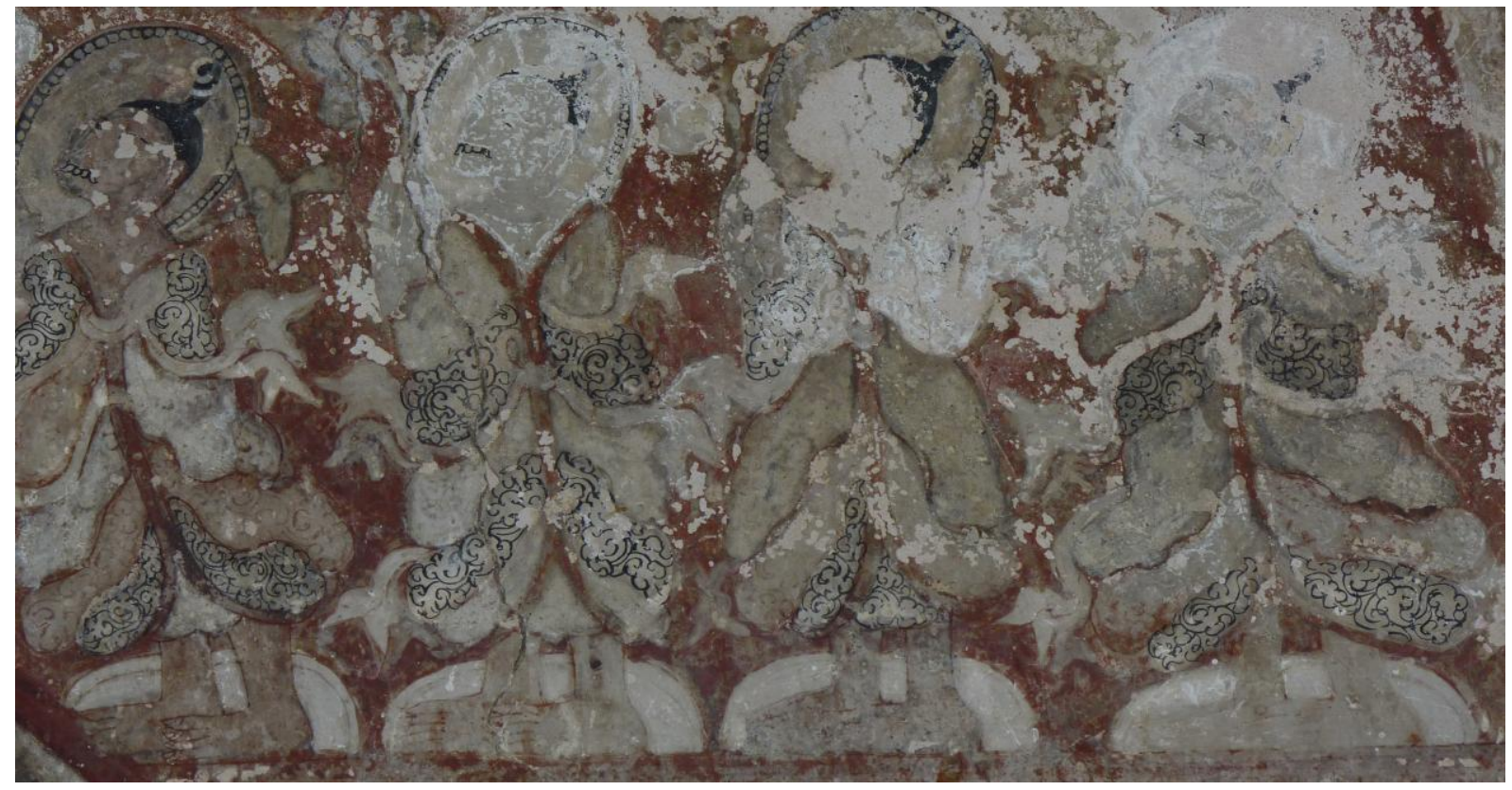

Fig. 13 
In the Nandamanya, the same characters dressed in heavy garments are introduced in the depiction of the 'war of relics'; as described in a previous paper; ${ }^{30}$ this scene faces the veneration of the Rāmagrāma caitya by the Nāgas, thus sharing the positioning noted in monument 1077. Eight such characters are distributed in two symmetric groups of four figures each (Figs. 11-13) in the lower row; above it, eight similar figures - but defaced are standing around a central group showing two horse-riders flanking Dona, shown standing with legs apart and hands raised to assuage the tensions between the eight rulers. It would thus appear that these eight figures should be the eight kings who carried the ashes of the Buddha back to their kingdoms. Their physical appearance is identical to that of the devotees in the Thambula, wearing heavy dress consisting of various layers of garments, adorned with foliated scrolls showing the spiked lobed leaf; ${ }^{31}$ their hair is knotted at the top of the head, and they wear moustaches. Here also, as in the donors' group in the Thambula, their importance is stressed by the presence of the nimbus behind their heads.

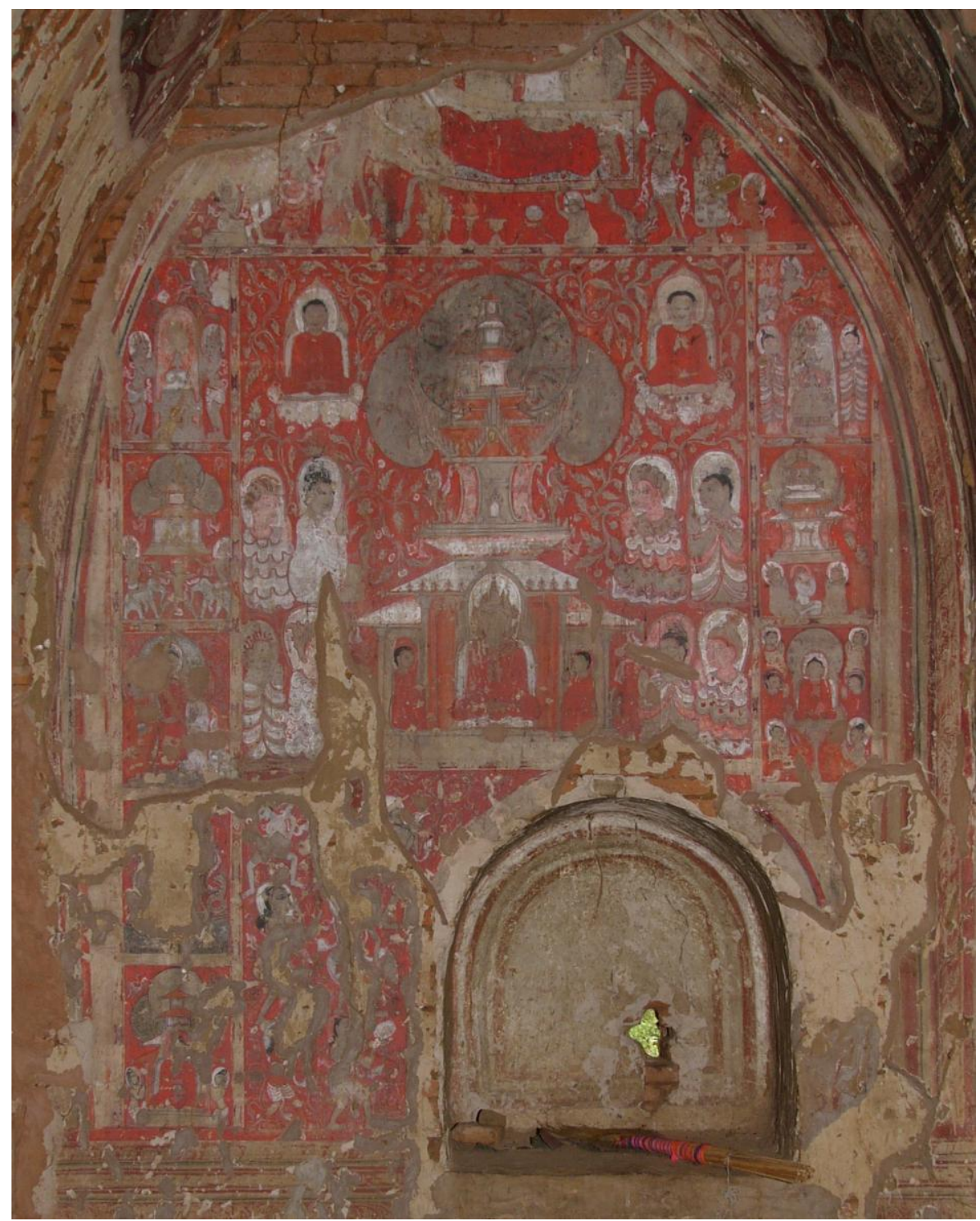

Fig. 14

\footnotetext{
${ }^{30}$ Bautze-Picron 2011: 11.

${ }^{31}$ On this very specific decorative Chinese motif, see our paper in press.
} 


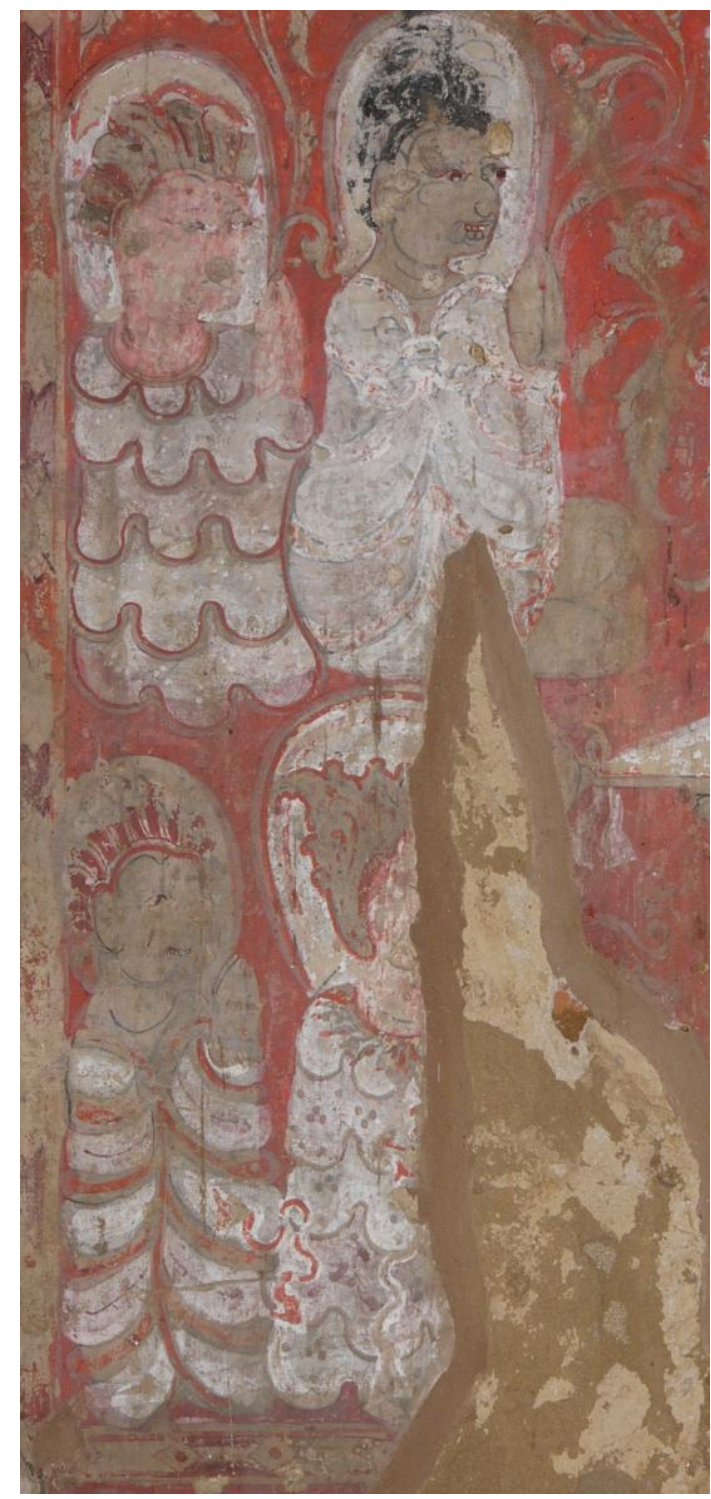

Fig. 15

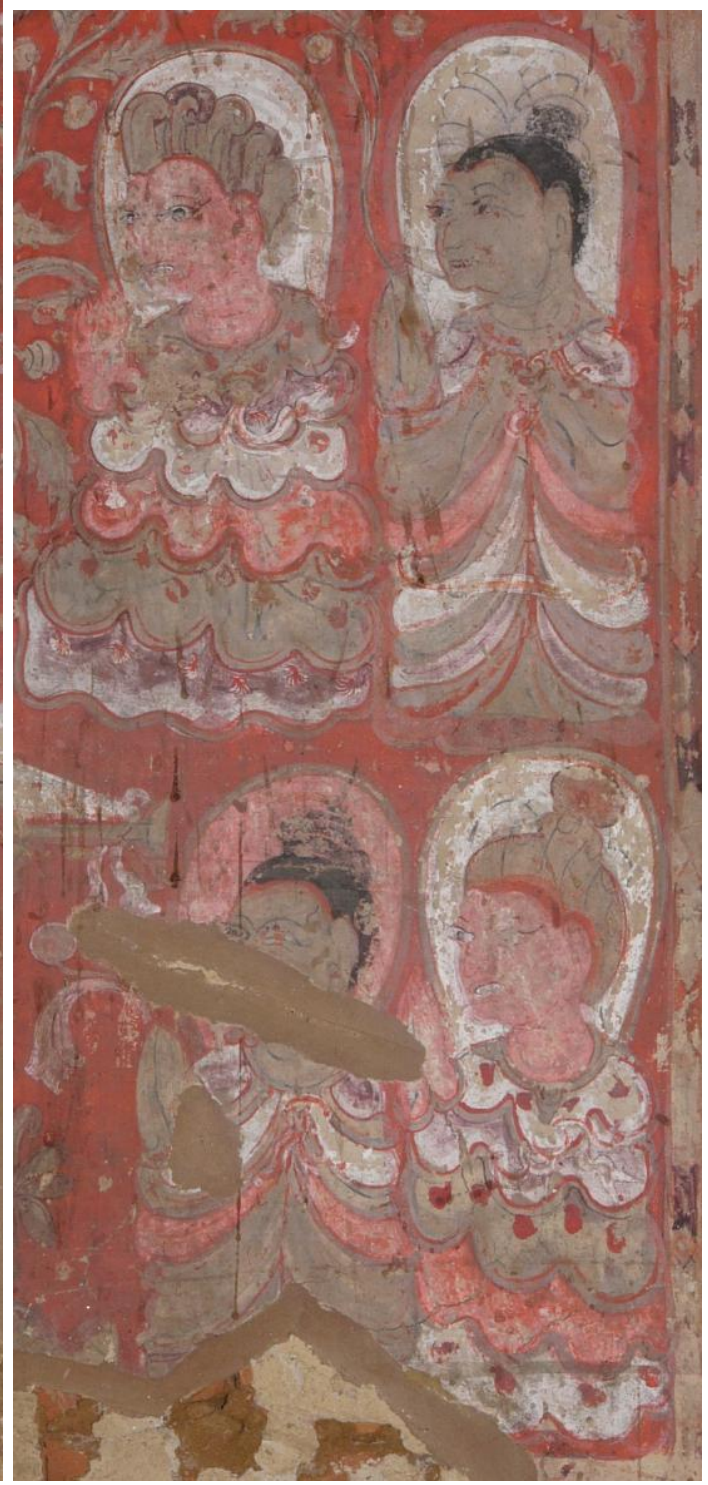

Fig. 16

Eight similar characters are depicted around the bejewelled Buddha on the south wall of monument 1077 (Figs 14-16), a presence which I tentatively tried to explain in a previous paper (2011, pp. 17-20). They are depicted paying their respects to the teaching Buddha, wearing heavy garments showing various kinds of pleating and different types of headdresses: the hair may be tied at the top of the head, as seen in the Thambula, but it may also be hidden under a hat, apparently inspired by the ornament noted in some Chinese paintings found at Khara Khoto. ${ }^{32}$ Whoever they may be, identifiable or not with characters belonging to Buddhist mythology, the major fact here is that such foreigners are held in such high consideration that they are distributed around the Buddha who is teaching, seated on his throne as a king (he is bejewelled) and flanked by Mahāmoggallāna and Sariputta, all three depicted within a shrine constructed in front of a tree whose foliage tops the composition.

\footnotetext{
${ }^{32}$ Piotrovsky 1993: 208-13, cats. 50 \& 51; see in particular the attending figures as illustrated on pp. 210211.
} 
The fact of having radically changed the looks of the eight Indian rulers who had collected the Buddha's ashes at Kuśinnagara probably reflects the historical reality: relations with India were then extinct and the central position held up to the thirteenth century by Bodhgaya, with Buddhists from all over Asia flocking, to it had waned whereas Bagan was stressing its position as protector of the Dharma in having its own Bodhi Mandir constructed around the mid-thirteenth century. ${ }^{33}$ This situation occurred in a period characterised not only by a shift of political interest towards China, but probably also by more extensive relations between monks from Bagan and the Chinese world. ${ }^{34}$

\section{Door-keepers at the Let-put-kan}

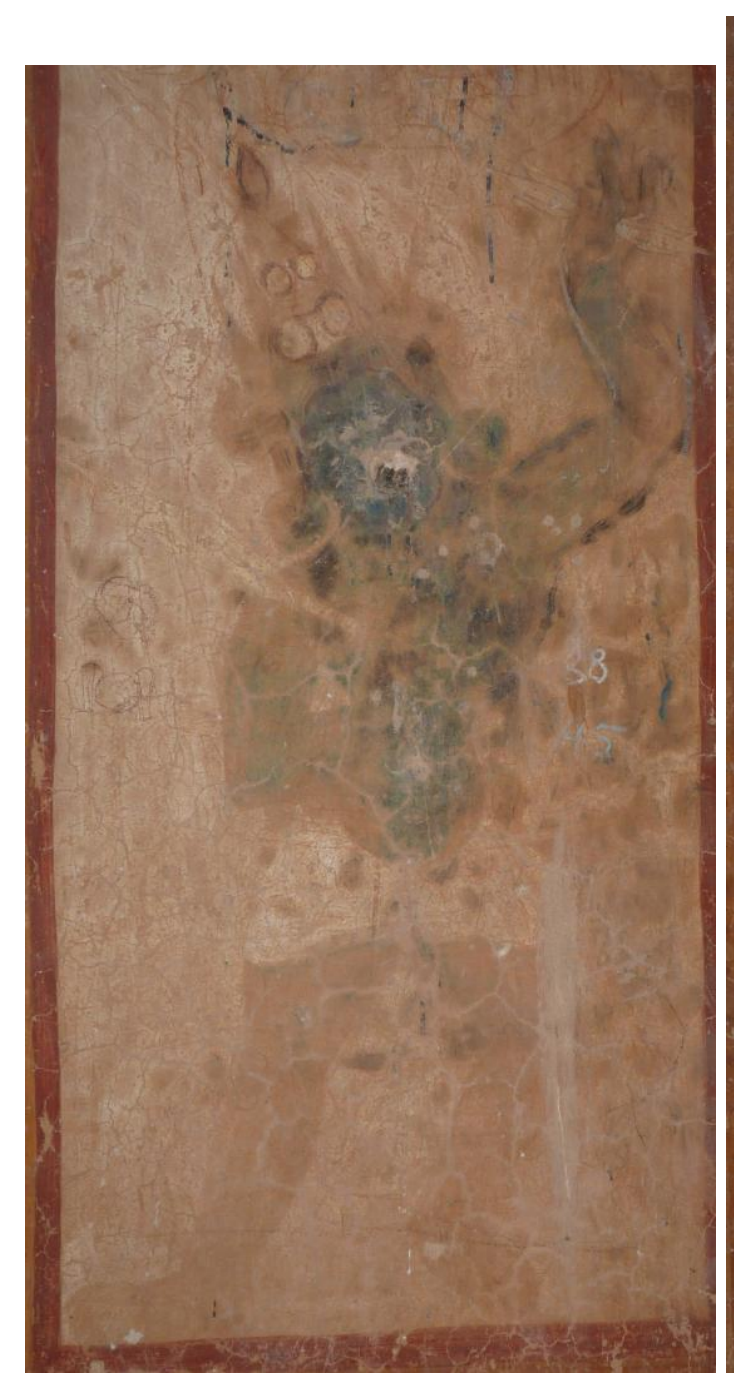

Fig. 17

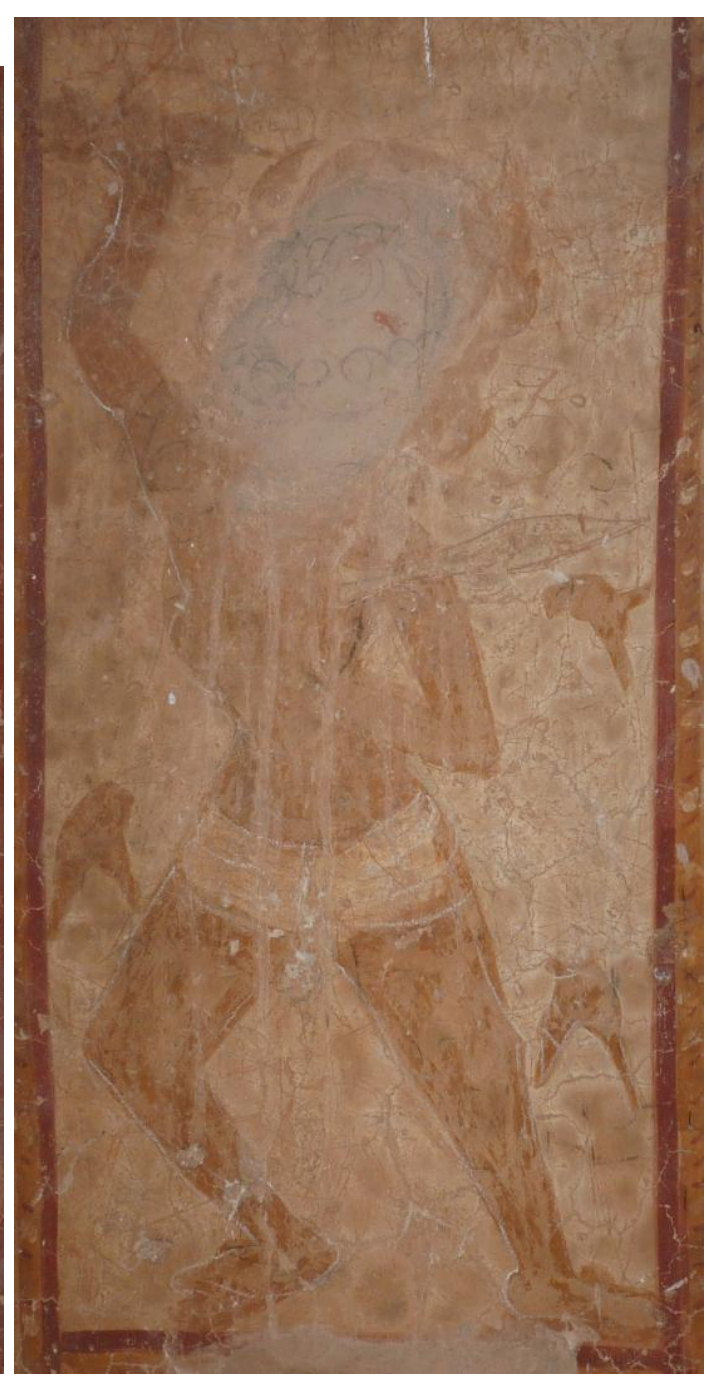

Fig. 18

We probably owe to this development the fearsome blue- or yellow-skinned male characters holding weapons such as a short sword and a vajra who are painted on the side

\footnotetext{
${ }^{33}$ Frasch 2000.

${ }^{34}$ On his return from his diplomatic mission to Beijing in 1285 , the monk Disāprāmuk was accompanied by 'monks from seventy monasteries ... who were to propagate Buddhism at Pagan' (Than Tun 1978: 32-34). See also Brose 2006: 337-8; Sen 2006: 304-5; and Geok Yian 2010 for a detailed study of this complicated question of the relationship between the kingdom of Bagan and China.
} 
walls of the entrances to the Let-put-kan (monument 711), a monument constructed before A.D. 1241 (Figs 17-18). ${ }^{35}$ Their facial features are startling, and they stand in the so-called àlïhasasana, a position of victory which also symbolizes their power and strength. Such characters are evidently related to the Krodha figures that appeared in the last phase of Buddhism in India and found their way to Tibet and Central Asia, but are clearly not part of the Buddhism which finds expression in the murals covering the inner walls of the monument where, as in all the other monuments, the main character is Śăkyamuni, and they also differ completely from Bodhisattvas acting as door-protectors noted in earlier monuments, such as the Abeyadana and the Kubyauk-gyi. ${ }^{36}$ Although they are much damaged and have been partly repainted, ${ }^{37}$ we can still recognize that they are heavily armed with vajra and sword in the western entrance, or with arrow (or ankuśa?) and an indistinct attribute or weapon in the eastern entrance.

These grim door-protectors were clearly added at a later date, most probably towards the end of the thirteenth century, and were not part of the initial iconographic programme which depicts the life of the Buddha through a series of panels distributed on the different walls of the shrine. Taking also into consideration the fact that these are isolated depictions in Bagan, we cannot consider them as evidence of the end of the Buddhist monasteries in Eastern India, which occurred around $1200,{ }^{38}$ but rather as a sign of connection with China: esoteric Buddhism was practiced by the Yuan rulers and in the Dali kingdom. ${ }^{39}$ The presence of such door-keepers at the entrances of a Bagan monument probably corroborates the presence at Bagan of monks of other than Theravāda obedience, probably those who had accompanied Disāprāmuk on his way back home. $^{40}$

\section{The army of Māra}

Throughout its history, representation of Māra's army attacking the Buddha has been the favoured setting for depicting those perceived as enemies to the Buddhist community. ${ }^{41}$ This is also apparently the case in thirteenth-century murals where, among the demons of the army, we note the presence of human soldiers (Fig. 19) fully protected by their

\footnotetext{
${ }^{35}$ Bautze-Picron 2003: 191-2: date after Pichard 1994a: 239-43.

${ }^{36}$ Bautze-Picron 2003: 93-103 and pls 103-106 for instance.

${ }^{37}$ In particular in the eastern entrance, where huge monstrous characters or bilus were painted over them at a much later date; these are probably contemporary with similar figures depicted at the Sulamani in 1778 A.D. (I owe this information to Alexandra Green ).

${ }^{38}$ As a matter of fact, the local testimonies of esoteric Buddhism, as known in Eastern India, are utmost rare and are limited to a few cast images imported from India (for instance Luce 1969-1970, III: pls. 426$428,445 a, 446 a-b, 447 a-d)$. Some of the fantastic characters seated or standing within a row of caves painted all along the corridor of the early twelfth-century Abeyadana are also clearly related to this phase (ibidem: pls 231-237).

${ }^{39}$ Howard 1997 or Bryson 2013, with further bibliographical references.

${ }^{40}$ Above note 34.

${ }^{41}$ In Eastern India, for instance, Hindu gods and goddesses belong to this army from the 10th century onward (Bautze-Picron 1996; 2010: 111-6). This iconography found its way up to the region of Chittagong and Bagan where in the $10^{\text {th }}-11^{\text {th }} \mathrm{c}$. murals, demons of the army still show features inherited from the Hindu deities (Bautze-Picron 2003: 109-14).
} 
lamellar armour, reminiscent of similar armour and coats worn by Chinese and Tibetan soldiers. ${ }^{42}$

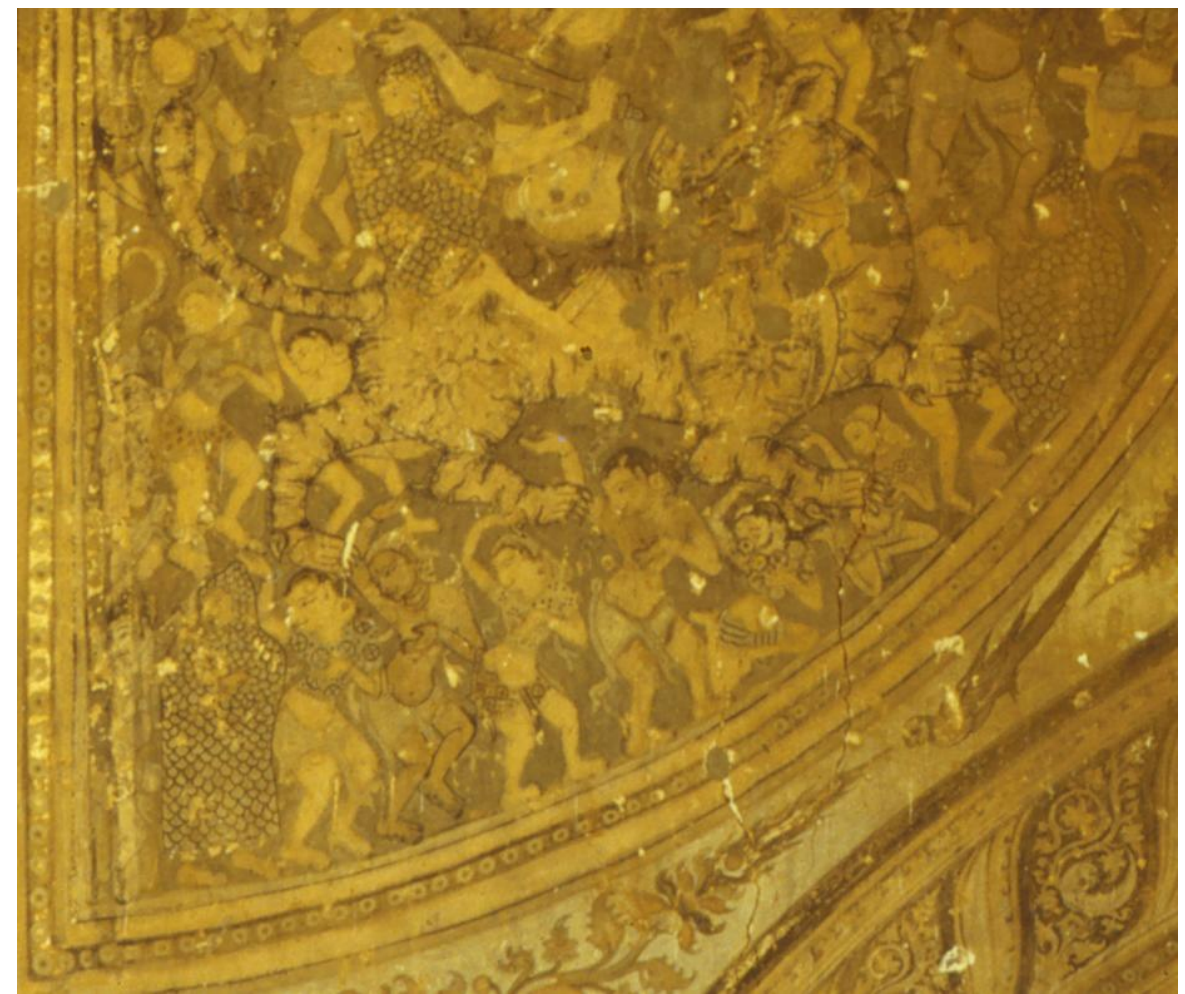

Fig. 19

\section{Kyanzittha-Umin}

This monument $\left(n^{\circ} 65\right)^{43}$ is not a shrine; it is built as if it had been excavated within a mountain: two concentric corridors overlapping at the back of the monument give access to nine rooms totally lacking natural light, which might have been used for meditation. Two larger rooms are built in the central space, accessible from the inner corridor. The date of the monument is debated ${ }^{44}$ but very clearly its murals are late (late thirteenthfourteenth century ?) and were not produced by professional artists, lacking the colours, the volumes, and the understanding of a logically constructed iconography distributed through the entire monument, as seen in most of the temples of Bagan. The lines are in fact rough, and the colours poor. The iconography mainly includes images of the Buddha as a teacher, but four panels show topics not encountered anywhere else and which do not appear to be related to canonical Buddhist iconography as seen in Bagan: a group of hunters (Fig. 20) is depicted on the inner wall of the back corridor, shooting arrows or holding a hawk. They were discovered and published by Charles Duroiselle, who identified them as Mongolian hunters. ${ }^{45}$ As a matter of fact, they can be compared with certain Mongolian characters, such as those depicted in the Diez Albums: their hats show

\footnotetext{
${ }^{42}$ Compare to LaRocca 2006: 55-64, cats 1-6.

${ }^{43}$ Duroiselle 1922; Luce 1969-1970, I: 256 \& 269; Pichard 1992: 134-6.

${ }^{44}$ Luce considers the monument to date from Kyanzittha's reign $\left(11^{\text {th }}-12^{\text {th }}\right.$ c.; hence its name) while Pichard dates it in the $13^{\text {th }} \mathrm{c}$., date which we would tend to ascribe to the murals (see previous note).

${ }^{45}$ Duroiselle 1922: 17-18 and plate I reproducing the sketches of two of them; these drawings were also (but poorly) by Than Tun 1976: figs. 3-4. Further pictures are reproduced by Pichard 1992: 136, figs 65j-k.
} 
a rather broad brim and flat crown $^{46}$ with feathers attached on top $;^{47}$ they are fully dressed, wearing boots and trousers, and bearing their quiver on their hip and a bird, probably a hawk, on their hand. The upper part of their dress is most probably made of brocaded silk with roundels spread all over - an ornamentation which finds an echo in textiles of the Yuan period. ${ }^{48}$

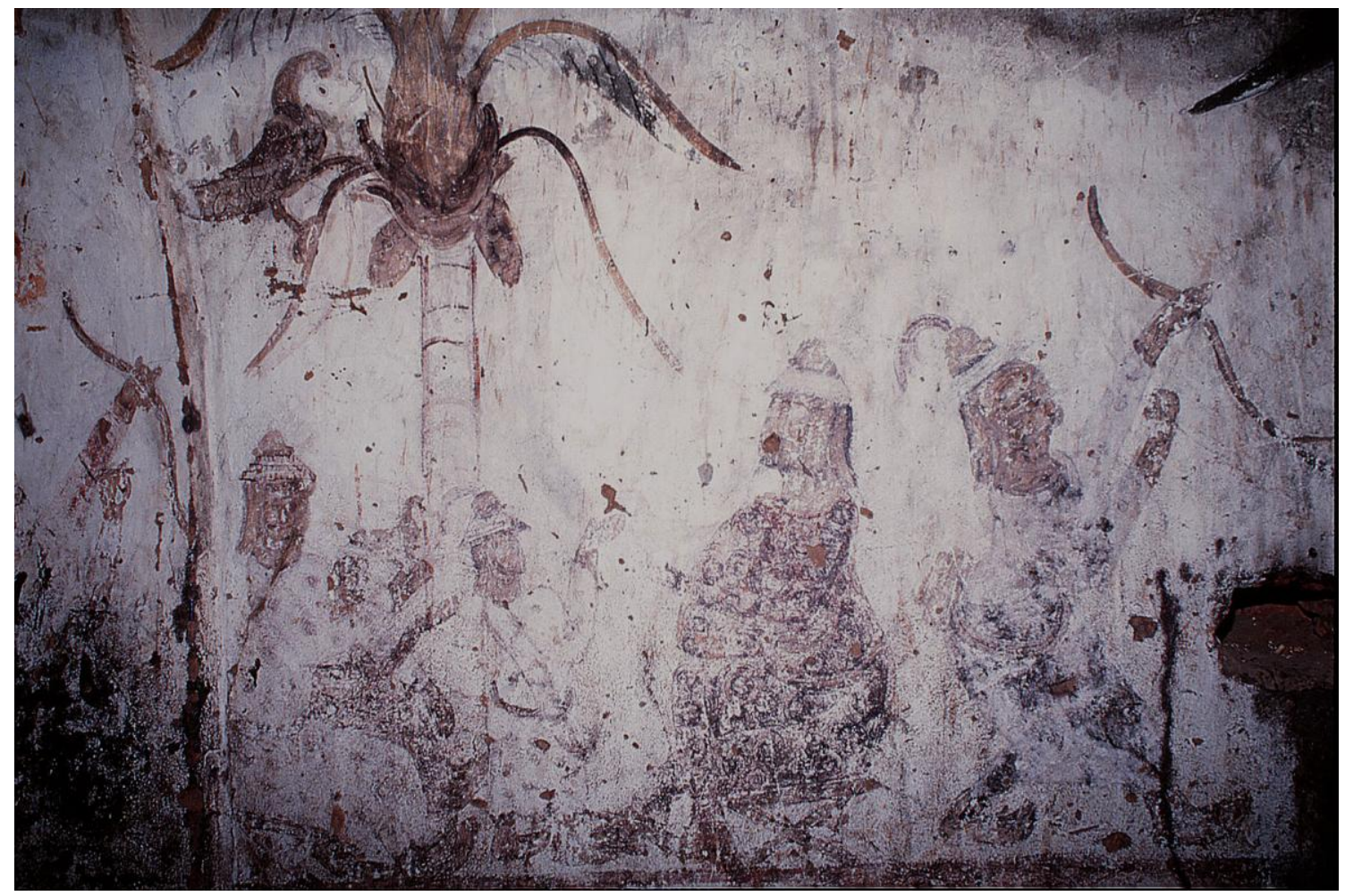

Fig. 20

In his description of the monument, Charles Duroiselle noted a panel painted above one of the four entrances - a square panel showing eight Christian crosses, which he relates to the Nestorian Church which was present in China (Fig. 21) ${ }^{49}$. A panel illustrating a different iconography is seen immediately above this one, showing a seated monk. A similar painting is to be seen in a niche on the eastern wall of the southern central room (Fig. 22). In both cases, the monk sits with crossed legs, wearing shoes; he wears a heavy garment which has folds clearly indicated in one case and a cape-like piece of clothing covering his shoulders. He sits with closed eyes, smiling gently; slightly bowed, he holds his bowl against his breast with both hands. The heavy dress and the shoes seem to designate him as a foreigner.

Taking into consideration his attitude and attribute, he could most probably be identified as the monk Upagupta or Upagutta: these two depictions introduce indeed an iconography which has survived to the present day, major differences being that the other

\footnotetext{
${ }^{46}$ Compare to Watt 2010: 79, fig. 111.

${ }^{47}$ See also Watt/Wardwell 1997: 96, fig. 38.

48 Watt/Wardwell 1997: 95, cat. 25; Watt 2010: 112-3, fig. 146. See further: Watt 2010: 76, fig. 106.

${ }^{49}$ Duroiselle 1922: 18-21; see also Guy 2010: 173-5 on the situation of the Nestorian Church in thirteenthcentury China.
} 
images of this monk known to us show him with open eyes, head looking up. ${ }^{50}$ Beside an inscribed panel in the Kubyauk-gyi, dated A.D. 1113, ${ }^{51}$ mention is made of Upagupta in a grammar written at Bagan in 1154, ${ }^{52}$ and he appears in the Lokapaññati, an 'eleventh-totwelfth-century Pali cosmological text' ${ }^{53}$ where he opposes Māra.

These two depictions include features which seem to refer to non-local habits, like wearing sandals or heavy dress. The cape-like pleated ornament seen in one case (Fig. 22) recalls a similar garment worn by Bodhisattvas in embroidered thankas and kāsāayas of the early Ming dynasty (1363-1424). ${ }^{54}$ These various elements might possibly indicate that the Kyanzittha-umin was, at a certain time, inhabited by monks who had travelled to China or who originated from there.

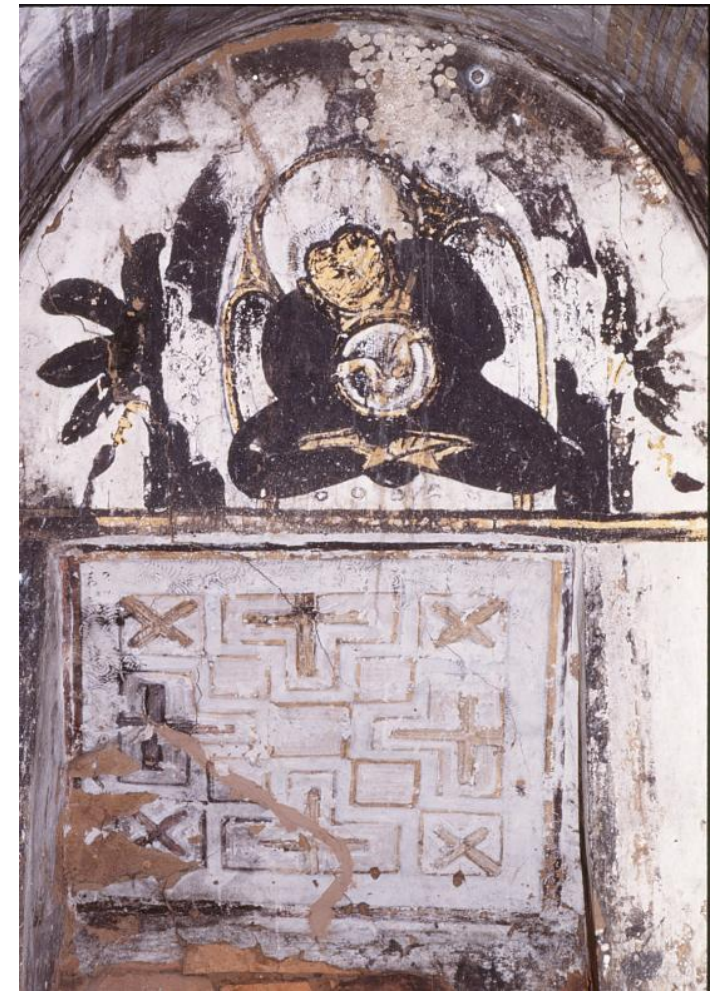

Fig. 21

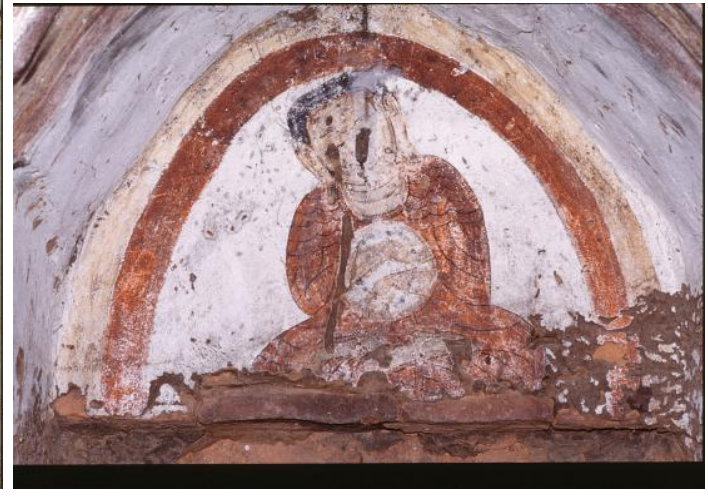

Fig. 22

\section{Conclusion}

Most observations made here concern monuments located on the outskirts of the site: the Kyanzittha-Umin is located north, not far from the Shwezigon; the Thambula, Let-putkan, Nandamanya, and Kathapa east are located in Minnanthu area situated in the southeast of the Bagan archaeological site; monument 1077 was built near the Irrawady, south of the village of Myinkaba, and the Thamuti-hpaya is situated midway between Minnanthu and Myinkaba. All the monuments, apart, possibly, from the Kyanzittha-

\footnotetext{
${ }^{50}$ Strong 1992: figs. 1, 5, 6 and 10. He is in fact looking at the sun, which he tries to hide, so that he can prolong the before-noon period when, as a monk, he is allowed to eat (Strong 1992: 156)

${ }^{51}$ Thus in a Theravādin context: Upagupta is here represented in a scene involving Aśoka on the side wall of a window (Luce/Ba Shin 1961: 385; Strong 1992: 12 \& 182).

${ }^{52}$ Strong 1992: 12.

${ }^{53}$ Strong 2004: 133; see also Strong 1992: 186-208.

${ }^{54}$ Watt/Wardwell 1997: 207-12, cats. 63-64.
} 
Umin, were constructed in the thirteenth century, and all the murals can be dated to the second half of this century, a period of intensive contacts between the Kingdom of Bagan and the Yuan Empire.

However, considering the highly diversified nature of the iconographic aspects of the Bagan murals considered above, it might seem difficult to get a coherent overall view. As a matter of fact, the similarity in the depiction of the Buddha noted in Khara Khoto and Bagan does not imply that the painters of the Khara Khoto tangka found their inspiration at Bagan, since the images in both sites might actually go back to the fundamental image standing at Bodhgaya. On the other hand, the unique presence of the cushion adorned with the lion face in the Thambula, the depiction of Krodhas protecting the entrances to the Let-put-kan, the row of heavily dressed devotees surrounding the northern entrance to the Thambula and their presence in iconographic topics in the Nandamanya, the Kathapa east and temple 1077, reflect the impact of Buddhism as practiced in China while also suggesting the presence in Bagan of Mongols or Chinese people, probably involved in trade or taking part in a diplomatic embassy from the middle of the thirteenth century onwards. ${ }^{55}$ These observations are consistent with those made when considering the decorative ornamentation of the murals of the thirteenth and early fourteenth centuries, which include numerous motifs decorating Chinese porcelain and garments. ${ }^{56}$

\section{Bibliography}

Asher, Frederick M. Bodh Gaya. New Delhi: Oxford University Press (Series Monumental Legacy), 2008.

Aung-Thwin, Michael A. Myth \& History in the Historiography of Early Burma, Paradigms, Primary Sources, and Prejudices, Athens, Singapore: Ohio University Center for International Studies, Monographs in International Studies, Southeast Asia Series No. 102/Institute of Southeast Asian Studies, 1998.

Bautze-Picron, Claudine. "Śăkyamuni in Eastern India and Tibet from the 11th to the 13th centuries." Silk Road Art and Archaeology, 4 (1995/96): 355-408.

Bautze-Picron, Claudine. "From God to Demon, from Demon to God: Brahmā and other Hindu deities in Late Buddhist Art of Eastern India." Journal of Bengal Art, 1 (1996): 109-135.

Bautze-Picron, Claudine. "Le groupe des huit Grands Bodhisatva en Inde: genèse et développement." Living a Life in Accord with Dhamma: Papers in Honour of Professor Jean Boisselier on his Eightieth Birthday, edited by Natasha Eilenberg, M.C. Subhadradis Diskul \& Robert L. Brown, Bangkok: Silpakorn University, 1997: 1-55.

Bautze-Picron, Claudine. "Between India and Burma: the 'andagu' stelae." The Art of Burma, New Studies, edited by Donald M. Stadtner. Mumbai: Marg Publications, vol. 50, 1999: 37-52.

\footnotetext{
${ }^{55}$ Aung-Thwin 1998: 66-69, also referring to a very badly preserved Chinese inscription at Bagan.

${ }^{56}$ See our forthcoming paper 'Between India and China: the Murals of Bagan' on this aspect of the relations between Bagan and China.
} 
Bautze-Picron, Claudine. The Buddhist Murals of Pagan, Timeless Vistas of the Cosmos, Photography: Joachim K. Bautze, Bangkok: Orchid Press, 2003.

Bautze-Picron, Claudine. The Bejewelled Buddha from India to Burma, New Considerations, New Delhi, Kolkata: Sanctum Books/Centre for Archaeological Studies \& Training, Eastern India, 2010 (Sixth Kumar Sarat Kumar Roy Memorial Lecture).

Bautze-Picron, Claudine. "The Murals of Temple 1077 in Pagan and their innovative Features", 2011. See: http://hal.archives-ouvertes.fr/hal-00638395/fr/

Bautze-Picron, Claudine. "Painted and architectural ornamentation of the temples of Pagan: More than mere iconography and decoration." Art of Merit, Studies in Buddhist Art and its Conservation, edited by David Park, Kuenga Wangmo \& Sharon Cather. London: Archetype, 2013: 66-85.

Bautze-Picron, Claudine. "Textiles from Bengal in Pagan (Myanmar) from Late Eleventh Century and Onwards." Studies in Heritage of South Asia, Essays in Memory of M. Harunur Rashid, edited by Mokammal H. Bhuiyan, 1-11. Dhaka: Heritage Management \& Research, 2014). See: https://hal.archives-ouvertes.fr/hal-00688718v2

Bautze-Picron, Claudine. "Between India and China: the Murals of Bagan.", Bagan and the World, Proceedings of 'Early Myanmar and its Global Connections', edited by John Miksic \& Goh Geok Yian. Singapore: Nalanda-Sriwijaya Centre (in press). See: https://hal.archives-ouvertes.fr/halshs-01079874v1

Brose, Michael C. "Realism and Idealism in the Yuanshi Chapters on Foreign Relations." Asia Major, 19 (2006): 327-47.

Bryson, Megan. "Mahākāla worship in the Dali kingdom (937-1253) - A study of the Dahei tianshen daochang yi." Journal of the International Association of Buddhist Studies 35.1-2, 2012(2013): 3-69.

Duroiselle, Charles. "34. Pictures of Mongols at Pagan, 35. Christian crosses at Pagan in the $13^{\text {th }}$ century." Report of the Superintendent, Archaeological Survey, Burma, for the year ending $31^{\text {st }}$ march 1922: 17-21.

Frasch, Tilman. Pagan, Stadt und Staat. Stuttgart: Franz Steiner Verlag (Beiträge zur Südasienforschung, Südasien-Institut, Universität Heidelberg), 1994.

Frasch, Tilman. "A Remark on the Mahabodhi Temples at Pagan." Southeast Asian Archaeology 1998, Proceedings of the $7^{\text {th }}$ International Conference of the European Association of Southeast Asian Archaeologists, Berlin, 31 August-4 September 1998, edited by Wibke Lobo and Stefanie Reimann, 41-49. Hull, Berlin: Centre for South-East Asian Studies/Ethnologisches Museum, Staatliche Museen zu Berlin, Stiftung Preußischer Kulturbesitz, 2000.

Geok Yian, Goh. "The question of 'China' in Burmese chronicles." Journal of Southeast Asian Studies 41.1 (2010): 125-52.

Godley, Michael R. "The End of the Queue: Hair as Symbol in Chinese History.", East Asian History 8 (December 1994): 53-72.

Guy, John. "Quanzhou: Cosmopolitan City of Faiths." The World of Khubilai Khan, Chinese Art in the Yuan Dynasty, edited by James C.Y. Watt, 159-78. New York, New Haven, London: The Metropolitan Museum of Art, Yale University Press, 2010.

Hearn, Maxwell K. \& Judith G. Smith, ed. Arts of the Song and the Yuan, Papers prepared for an international symposium organized by The Metropolitan Museum of Art 
in conjunction with the exhibition Splendors of Imperial China: Treasures from the National Palace Museum, Taipei. New York: The Metropolitan Museum of Art, 1996.

Howard, Angela F. "The Dhāran̄ī Pillar of Kunming, Yunnan. A Legacy of Esoteric Buddhism and Burial Rites of the Bai People in the Kingdom of Dali (937-1253)." Artibus Asiae 57 (1997): 33-72.

Huntington, Susan L. "Some Bronzes from Fatehpur, Gaya." Oriental Art, N.S., XXV.2 (1979): 240-47.

Kim, Jinah. Receptacle of the Sacred, Illustrated Manuscripts and the Buddhist Book Cult in South Asia. Berkeley, Los Angeles, London: University of California Press, 2013.

LaRocca, Donald J. et alii. Warriors of the Himalayas, rediscovering the arms and armor of Tibet. New Haven, Conn.: Yale University Press, 2006. [Exhibition Warriors of the Himalayas: Rediscovering the Arms and Armor of Tibet on view at The Metropolitan Museum of Art, New York, April 5 - July 2, 2006].

Leoshko, Janice. "The Issue of Influence in Burmese Art." Makaranda, Essays in Honour of Dr. James C. Harle, edited by Claudine Bautze-Picron, 185-8. Delhi: Sri Satguru Publications, 1990.

Luce, G.H \& Bohmu Ba Shin. "Pagan Myinkaba Kubyauk-gyi Temple of Rājakumār (1113 A.D.) and the old Mon Writings on its Walls." Bulletin of the Burma Historical Commission, II (1961, published in 1963): 277-416.

Luce, Gordon H. Old Burma Early Pagán. New York: J.J. Augustin Publisher, Locust Valley for Artibus Asiae \& The Institute of Fine Arts, New York University, 1969-1970.

Lutz, Albert. Der Tempel der drei Pagoden von Dali, Zur buddhistischen Kunst des Nanzhao- und Dali-Königreichs in Yunnan, China. Zürich: Museum Rietberg, 1991.

Lutz, Albert (ed.). Der Goldschatz der drei Pagoden, Buddhistische Kunst des Nanzhaound Dali-Königreichs in Yunnan. China, Zürich: Museum Rietberg, 1991.

Menzies, Jackie (ed.). Buddha, Radiant Awakening. Sydney: Art Gallery of New South Wales, 2001.

Mitra, Debala. "Some Images from Jaipur (District Gaya)," Kusumāã̃ali, New Interpretration of Indian Art \& Culture, Sh. C. Sivaramamurti Commemoration Volume, edited by M.S. Nagaraja Rao, II, 323-33. Delhi: Agam Kala Prakashan, 1987.

Pal, Pratapaditya. "The story of a wandering bronze Buddha - and two examples from American collections." The Connoisseur, 181 (1972): 203-7.

Pichard, Pierre. Inventory of Monuments at Pagan, Inventaire des Monuments, volume One, Monuments 1-255, Paris, Gartmore: EFEO, UNESCO, Kiscadale, 1992.

Pichard, Pierre. Inventory of Monuments at Pagan, Inventaire des monuments, Volume Two, Monuments 256-552. Paris, Gartmore: Kiscadale, EFEO, UNESCO, 1993.

Pichard, Pierre. Inventory of Monuments at Pagan, Inventaire des monuments, Volume Three, Monuments 553-818. Paris, Gartmore: Kiscadale, EFEO, UNESCO, 1994 (1994a).

Pichard, Pierre. Pagan, Inventory of Monuments/Inventaire des monuments, Volume Four, Monuments 819-1136. Paris, Gartmore: Kiscadale, EFEO, UNESCO, 1994 (1994b).

Piotrovsky, Mikhail (ed.). Lost Empire of the Silk Road, Buddhist Art from Khara Khoto (X-XIIIth century). Milano: Electa, Thyssen-Bornemisza Foundation, 1993. 
Rhie, Marylin M. \& Robert A.F. Thurman. Wisdom and Compassion, The Sacred Art of Tibet. London: Thames and Hudson (published on the occasion of an exhibition organized by the Asian Art Museum of San Francisco in conjunction with Tibet House, New York), 1991.

Sahai, Bhagwant. "The Bronzes from Fatehpur." The Journal of the Bihar Purāvid Parishad I (1977): 173-86.

Sen, Tansen. "The Yuan Khanate and India: Cross-Cultural Diplomacy in the Thirteenth and Fourteenth Centuries." Asia Major 19 (2006): 299-326.

Sharma, Brijendra Nath. "Pāla Bronzes from Fatehpur, Gaya." East and West 29 (1979): 127-130.

Sotheby's New York. Indian and Southeast Asian Art, Sale 7280, Thursday, March 25, 1999, New York: Sotheby's.

Stoddard, Heather. Early Sino-Tibetan Art, Bangkok: Orchid Press, 2008.

Strong, John S. The Legend and Cult of Upagupta, Sanskrit Buddhism in North India and Southeast Asia. Princeton, New Jersey: Princeton University Press, 1992.

Strong, John S. Relics of the Buddha, Princeton, Oxford: Princeton University Press, 2004.

Than Tun. "Saraswatī of Burma." South East Asian Studies 14.3 (1976): 433-41.

Than Tun. "History of Buddhism in Burma A.D. 1000-1300." Journal of The Burma Research Society. LXI/I \& II (1978): 1-266.

von Schroeder, Ulrich. Buddhist Sculptures in Tibet, Volume One, India and Nepal. Hong Kong: Visual Dharma Publications Ltd., 2001.

von Schroeder, Ulrich. 108 Buddhist Statues in Tibet. Chicago, Hong Kong: Serindia Publications, Visual Dharma Publications Ltd., 2008.

Watt, James C.Y. (ed.). The World of Khubilai Khan, Chinese Art in the Yuan Dynasty. New York, New Haven, London: The Metropolitan Museum of Art, Yale University Press, 2010.

Watt, James C.Y. \& Anne E. Wardwell. When Silk was Gold, Central Asian and Chinese Textiles. New York: The Metropolitan Museum of Art, 1997.

Weldon, David \& Jane Casey Singer. The Sculptural Heritage of Tibet, Buddhist Art in the Nyingjei Lam Collection. London: Laurence King, 1999.

Zwalf, W. (ed.). Buddhism, Art and Faith, London: Published by the British Museum Publications Limited The Trustees of the British Museum and the British Library Board, 1985.

\section{Illustrations}

Unless otherwise mentioned, all photos are courtesy of Joachim K. Bautze.

1. Buddha, Thambula: northern side of the central core

2. Buddha, Thambula: murals in the eastern hall, western wall

3. Buddha, Thamuti-hpaya 
4. Buddha, cloth-painting, Khara Khoto, Hermitage, St Petersburg, after: Piotrovsky 1993, cat. 6 .

5. Cushion under the Buddha, detail of Fig. 2

6. Buddha, Bihar, Potala Museum, Lhasa, photo courtesy of Ulrich von Schroeder

7. Group of foreigners flanking the northern entrance, Thambula

8. Detail of the murals on the northern entrance, Thambula

9. Detail of the murals on the northern entrance, Thambula

10. Two foreigners worshipping a stūpa, Temple 1077, southern wall

11. Group of eight foreign rulers, southern wall, Nandamanya

12. Left part of the group of eight foreign rulers, Nandamanya

13. Right part of the group of eight foreign rulers, Nandamanya

14. Temple 1077, southern wall

15. Detail of the mural in temple 1077, southern wall, left group

16. Detail of the mural in temple 1077, southern wall, right group

17. Door-keeper, western entrance, Let-put-kan

18. Door-keeper, western entrance, Let-put-kan

19. Foreign soldiers among Māra's army, Kubyauk-gyi, Wetkyi-in

20. Mongols hunters, Kyanzittha-umin, southern corridor, northern wall

21. Upagupta, Kyanzittha-umin, mural above an entrance

22. Upagupta, Kyanzittha-umin, central room, eastern wall 